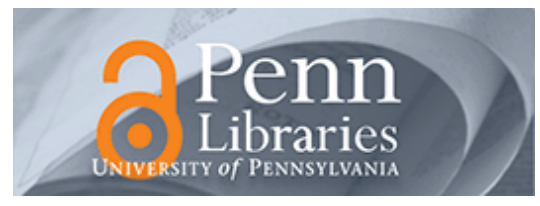

University of Pennsylvania

ScholarlyCommons

Accounting Papers

Wharton Faculty Research

2000

\title{
Corporate Disclosure Practices, Institutional Investors, and Stock Return Volatility
}

Brian J. Bushee

University of Pennsylvania

Christopher F. Noe

Follow this and additional works at: https://repository.upenn.edu/accounting_papers

Part of the Accounting Commons

\section{Recommended Citation}

Bushee, B. J., \& Noe, C. F. (2000). Corporate Disclosure Practices, Institutional Investors, and Stock Return Volatility. Journal of Accounting Research, 38 171-202. http://dx.doi.org/10.2307/2672914

This paper is posted at ScholarlyCommons. https://repository.upenn.edu/accounting_papers/60

For more information, please contact repository@pobox.upenn.edu. 


\title{
Corporate Disclosure Practices, Institutional Investors, and Stock Return Volatility
}

\begin{abstract}
This paper investigates whether the quality of a firm's disclosure practices affects the composition of a firm's institutional investor base and whether this association has implications for a firm's stock return volatility. The findings indicate that firms with higher disclosure quality, as measured by AIMR rankings, have greater institutional ownership, but the particular types of institutional investors that are attracted to disclosure quality tend to have no net impact on firms' stock return volatility. In contrast, improvements in disclosure quality are shown to produce contemporaneous increases in ownership primarily by transienttype institutions. Such institutions can be characterized as having a short-term investment focus along with a propensity to trade aggressively. The findings indicate that firms with disclosure quality improvements resulting in higher transient institutional investor ownership experience subsequent increases in stock return volatility.
\end{abstract}

Disciplines

Accounting 


\title{
DISCLOSURE QUALITY, INSTITUTIONAL INVESTORS, AND STOCK RETURN VOLATILITY
}

\author{
Brian J. Bushee \\ Visiting Assistant Professor of Accounting \\ Graduate School of Business \\ University of Chicago \\ 1101 East $58^{\text {th }}$ St. \\ Chicago, IL 60637 \\ bbushee@hbs.edu
}

\author{
Christopher F. Noe \\ Assistant Professor of Business Administration \\ Graduate School of Business Administration \\ Harvard University \\ Boston, MA 02163 \\ cnoe@hbs.edu
}

October 1999

\footnotetext{
The authors would like to thank Mary Barth, Mark Bradshaw, Bob Bowen, Dave Burghstahler, Paul Healy, Amy Hutton, Bjorn Jorgensen, James Myers, Greg Miller, Nancy Rothbard, Krishna Palepu, Ray Pfeiffer, Abbie Smith, Brett Trueman and workshop participants at the 1999 AAA annual meeting, the Australian Graduate School of Management, Harvard University, MIT, Northwestern University, the University of Sydney, the 1999 Stanford University Summer Camp, and the University of Washington for helpful comments and suggestions. Subsets of the AIMR data used in this paper were generously provided by Amy Hutton, Russ Lundholm, and Linda Myers.
} 


\title{
DISCLOSURE QUALITY, INSTITUTIONAL INVESTORS, AND STOCK RETURN VOLATILITY
}

\begin{abstract}
This paper investigates whether the quality of a firm's disclosure practices affects the composition of a firm's institutional investor base and whether this association has implications for a firm's stock return volatility. The findings indicate that firms with higher disclosure quality, as measured by AIMR rankings, have greater institutional ownership, but the particular types of institutional investors that are attracted to disclosure quality tend to have no net impact on firms' stock return volatility. In contrast, improvements in disclosure quality are shown to produce contemporaneous increases in ownership primarily by transient-type institutions. Such institutions can be characterized as having a short-term investment focus along with a propensity to trade aggressively. The findings indicate that firms with disclosure quality improvements resulting in higher transient institutional investor ownership experience subsequent increases in stock return volatility.
\end{abstract}




\section{INTRODUCTION}

In recent years, an increasing number of corporate managers have hired investor relations consulting firms to help them attract certain types of investors to their stock. These consulting firms generally advocate targeting institutional investors with long investment horizons, and screening out investors that trade frequently, with the goal of achieving a stable ownership base that will not destabilize a firm's stock price based on short-term developments (Anand [1991], Elgin [1992], Byrne [1999]). These targeting activities often involve more forthcoming disclosure practices and specially tailored road shows presentations (Lev [1991], Elgin [1992], Byrne [1999]). However, recent anecdotes in the popular press indicate that providing more guidance may attract institutional investors that trade aggressively and actually cause more volatile reactions to announcements (Fox [1997], Serwer [1997]). ${ }^{\square}$ Both of these phenomena imply there are important links between a firm's disclosure practices, the composition of its institutional ownership, and the volatility of its stock price.

Prior research has provided evidence on each of these links individually. Lang and Lundholm [1993] find that, contrary to expectations, disclosure quality is positively associated with stock return volatility. They conjecture that stock return volatility proxies for information asymmetry, which managers are trying to reduce through higher levels of disclosure. Healy, Hutton, and Palepu [1999] report that sustained increases in disclosure quality result in higher levels of institutional ownership, which they cite as a benefit of improving disclosure quality. However, Sias [1999] and Potter [1992] both provide evidence that higher institutional ownership is associated with higher stock return volatility. These latter two findings raise the

\footnotetext{
${ }^{1}$ For example, Fox [1997] argues that "The downside of giving better guidance... is that investors most interested in [earnings] estimates are not exactly the well-run corporation's best friend. They are the momentum guys-mutual fund managers and hedge fund jockeys and individual investors - who jump on the bandwagon when a company's earnings growth is accelerating and beating the analysts' estimates, and jump off the second it misses a quarter."
} 
possibility that the positive association between disclosure quality and stock return volatility found in Lang and Lundholm [1993] is due to an indirect link between disclosure quality and volatility through the attraction of institutional investors. In this paper, we classify institutional investors based on their expected preferences for disclosure quality and their expected impact on stock return volatility to examine this potential indirect link of disclosure quality on volatility.

We categorize institutions based on various aspects of their trading behavior and find significant differences in the sensitivity of institutional investors to disclosure quality, as measured by AIMR rankings of firm's disclosure practices. The results indicate that transient institutions, which trade aggressively based on short-term news, invest more heavily in firms with higher disclosure quality and increase their holdings in response to increases in disclosure quality. These results are consistent with transient institutions valuing high disclosure because it lessens the price impact of trades, facilitating the realization of short-term trading gains. Quasiindexer institutions, which hold large, diversified portfolios and trade very infrequently, also invest more heavily in firms with higher disclosure quality. However, they tend to sell firms that have decreases in disclosure quality but not immediately increase holdings in firms with disclosure improvements. This evidence is consistent with quasi-indexers relying on public disclosures as a low-cost mechanism of monitoring firm performance in their portfolio. Finally, dedicated institutions, which are characterized by large, stable holdings in a small number of firms, show no sensitivity to disclosure quality levels or changes, suggesting that these institutions rely on sources of information other than public disclosure.

We use these findings to examine the direct and indirect effects of disclosure quality on stock return volatility. The results indicate that high levels of disclosure have the direct effect of lowering subsequent stock return volatility. We also find that higher levels of transient 
ownership are associated with higher stock return volatility, which combined with the result that disclosure quality is positively associated with transient ownership, indicates that disclosure quality has the indirect effect of increasing stock return volatility through the attraction of transient institutions. However, this indirect effect is almost completely offset by the fact that higher quasi-indexer ownership, which is also associated with higher disclosure quality, is associated with lower stock return volatility. Thus, managers with high disclosure quality actually experience relatively lower stock price volatility if they attract both quasi-indexer and transient institutions, as the indirect volatility effects of attracting these types of institutions through high disclosure quality cancel each other out.

When managers significantly change the quality of their disclosure practices, these indirect effects no longer offset each other. We find that changes in transient ownership are positively associated with future changes in stock return volatility, while changes in ownership by quasi-indexers and dedicated institutions do not precede volatility changes. As a result, improvements in disclosure that attract transient institutions result in an increase in stock return volatility that is not offset by the attraction of quasi-indexers.

These findings contribute to the voluntary disclosure literature by suggesting that improving disclosure quality may lead to an important indirect cost, namely attracting a shortsighted institutional investor base that results in a more volatile stock price. Prior disclosure studies have documented many beneficial capital markets effects associated with firms improving their disclosure practices, including lower equity and debt costs (Botosan [1997], Sengupta [1998]), narrower bid-ask spreads (Welker [1995], Healy, et al. [1999], Leuz and Verrecchia [1999]), and improved stock price responsiveness to earnings (Price [1998]). Moreover, this research has also found that disclosure quality improvements are associated with 
improved analyst following and increased institutional investor ownership (Lang and Lundholm [1996], Healy, et al. [1999]). Our work indicates that attracting institutional ownership with improved disclosure is not always beneficial and managers faced with decisions about whether to change their firms' disclosure practices should weigh any potential benefits of improved disclosure quality against the possibility of exacerbating stock return volatility.

This paper also contributes to the literature on institutional investors and stock return volatility, which has produced conflicting findings up to this point. Potter [1992] documents a positive association between the level of institutional investor holdings in a firm and the level of stock return volatility on days surrounding earnings announcements. In contrast, El-Gazzar [1998] finds a negative association using a different sample period and a different set of control variables. Gompers and Metrick [1998] document a negative contemporaneous association between annual stock return volatility and institutional ownership, but Sias [1996] finds that increases in institutional investor holdings precede increases in stock return volatility. This paper finds that both levels of and changes in stock return volatility, measured both annually and around earnings announcements, appear to be partly driven by shifts in the composition of institutional investor holdings of firms. In particular, increased holdings by transient institutions are associated with subsequently heightened stock return volatility.

The remainder of this paper is organized as follows. Section 2 discusses the potential links between disclosure practices, different types of institutional investors, and stock return volatility. Section 3 describes the data used in our tests. Section 4 presents empirical results on the association between disclosure quality and institutional ownership and section 5 reports results on the effects of disclosure quality and institutional ownership on stock return volatility. Finally, section 6 provides a summary and conclusions. 


\section{EMPIRICAL PREDICTIONS}

\subsection{Disclosure quality and institutional ownership}

Institutional investors could be sensitive to a firm's disclosure quality for a number of reasons. First, institutional investors could be attracted to firms with better disclosure if it reduces the price impacts of trades (Healy, Hutton, and Palepu [1999]). Prior research finds that institutions tend to invest more heavily in firms with greater average trading volumes, consistent with institutions preferring firms for which trades are likely to have a lower price impact (Falkenstein [1996], Gompers and Metrick [1998]). Diamond and Verrecchia [1991] show that a high level of disclosure reduces the information asymmetry between the firm and investors, which lessens potential price impacts of trades by reducing both bid-ask spreads and the amount of information potentially revealed by large trades. 2

Second, institutions could be sensitive to disclosure quality if it affects potential profit opportunities in a firm's stock. Profit opportunities could be eroded if firms' disclosures provide a substitute for private information collection or if they reveal proprietary information to the market, impairing a firm's long-run value. Alternatively, Kim and Verrecchia [1994] argue that the profit making ability of sophisticated investors lies in their superior ability to interpret the implications of public signals. Thus, the effect of disclosure quality on the profit opportunities of an institution likely depends on its information gathering and processing capabilities.

Finally, disclosure quality could be important to institutions if they rely on public disclosures to monitor the firm and determine when to engage in corporate governance activities. Bushman et al. [1999] argue that a "critical input to the effective operation of corporate

\footnotetext{
${ }^{2}$ Welker [1995], Healy, Hutton, and Palepu [1999], and Leuz and Verrecchia [1999] provide empirical evidence that higher disclosure quality is associated with greater stock market liquidity, proxied by lower bid-ask spreads.
} 
governance mechanisms is information about how equity value is changing and why" (p. 1). Smith [1996] reports that CALPERS uses "screens" based on public data to choose which of its portfolio firms to target for shareholder activism. Thus, institutions that choose to be active in corporate governance and/or do not have the resources to engage in private information collection will likely prefer firms with better quality disclosure.

Thus, the overall importance of disclosure quality to institutional investors depends on their investment horizons, information gathering capabilities, and governance activities. To capture key differences on these dimensions, we use the methodology of Bushee [1998, 1999] to separate institutions into three groups based on prior investment behavior. The first group of institutions, called "transient" institutions, is characterized as having high levels of portfolio turnover and diversification. These characteristics reflect the fact that transient institutions tend to be short-term focused investors with little interest in long-term capital appreciation or dividends (Porter [1992]). Because transient institutions focus on attaining short-term returns from their position in a firm's stock, high liquidity will be important to them so that the price impact of their trading does not erode any potential trading gains. Also, richer disclosure could provide more basis for short-term differences in opinions between investors and hence more opportunity for near-term trading profits. ${ }^{\text {B }}$ Thus, transient institutions are likely to be attracted to firms with higher levels of disclosure.

The second group of institutions, called "dedicated" institutions, is characterized as taking large stakes in firms and having low portfolio turnover, both of which are consistent with a "relationship" approach to investing (Porter [1992], Dobrzynski [1993]). Due to their large, stable ownership positions, dedicated institutions often have better access to private information 
about their portfolio firms (Porter [1992]). As a result, public disclosure is less important in monitoring the firm, and is potentially costly if it reveals private, proprietary information. Because dedicated institutions are not frequent traders, the liquidity benefits of good disclosure are likely to be less important to them than to other types of institutions. Thus, dedicated institutions are likely to be indifferent to disclosure quality or even prefer firms with lower disclosure quality.

The final group of institutions, called "quasi-indexers," is characterized as having low portfolio turnover and highly diversified holdings. These characteristics suggest a passive, buyand-hold strategy of investing (Porter [1992]). This strategy is prevalent among institutions like public pensions and bank trusts, which have substantial sums to invest and/or lack the resources to actively manage their portfolio. Like dedicated institutions, the low portfolio turnover of these institutions limits the importance of disclosure in reducing price impacts of trading. However, for quasi-indexers with large, diversified portfolios, public disclosures are often the most costeffective method of monitoring firm performance, indicating that quasi-indexers should prefer higher disclosure quality.

We examine the sensitivity of institutional investors to disclosure quality using both a levels and a changes approach. Consistent results across these two approaches increase our confidence that institutional investors are responding to the benefits of disclosure per se rather than to some omitted factor that is associated with either disclosure levels or changes (e.g., a restructuring event that leads to increased disclosure and also affects institutional ownership). Moreover, the changes test provides a timeliness measure of how quickly institutions respond to changes in disclosure regimes. Based on their propensity to trade, we expect transient

\footnotetext{
${ }^{3}$ This notion is supported by Froot, Scharfstein, and Stein [1992], who show that short-term speculators have incentives to herd on the same pieces of information as other short-term traders, a process which could be facilitated
} 
institutions to respond more quickly to changes in disclosure than either quasi-indexer or dedicated institutions.

\subsection{Disclosure quality, institutional ownership, and stock return volatility}

One commonly cited benefit of high disclosure quality is that, by mitigating information asymmetry, it reduces the magnitude of periodic surprises and makes a firm's stock price less volatile (Lang and Lundholm [1993], Healy, Hutton, and Palepu [1999]). High stock price volatility is potentially undesirable for firms because it can increase the likelihood of a lawsuit in the wake of a big stock price decline (Lang and Lundholm [1993]), increase the firm's perceived riskiness and cost of capital (Froot, Perold, and Stein [1992]), and make price-based compensation less effective and/or more costly (Baiman and Verrecchia [1995], Jorgensen [1998]).

Prior research provides mixed evidence on whether higher disclosure quality is associated with lower stock return volatility. Patell [1976] reports evidence that firms' stock return volatility drops in the weeks after a voluntary earnings forecast. However, Lang and Lundholm [1993] find mixed evidence of whether total disclosure quality measured over a longer period is positively or negatively associated with stock return volatility. They conjecture that a positive association could result if stock return volatility proxies for information asymmetry and managers are improving disclosure to reduce this asymmetry.

Another explanation for a positive association is that high disclosure quality indirectly leads to higher stock return volatility by attracting greater holdings by transient institutions, whose more aggressive trading behavior results in higher volatility. Prior research suggests that high levels and large changes of institutional ownership lead to higher future stock return volatility (Sias [1996], Potter [1992]). Although this research has not specifically examined 
whether this increase in volatility is driven by transient institutions, these institutions likely drive this association given their high turnover and alleged propensity to engage in large-scale selling when faced with bad news (Porter [1992]). Thus, high quality disclosure that attracts transient institutions should indirectly result in higher stock return volatility, certeris paribus.

Alternatively, if high disclosure quality attracts quasi-indexer or dedicated institutions, then disclosure quality could have an additional, indirect effect of lowering stock return volatility due to the passive trading behavior of these institutions. The goal of our empirical tests is to separate the direct effect of disclosure quality on stock return volatility from these indirect effects of disclosure quality on volatility through the attraction of different types of institutional investors.

We test the effect of disclosure quality and institutional ownership on future stock return volatility using both a levels and a changes approach. We examine future stock return volatility to test whether having a certain composition of institutional ownership resulting from disclosure practices (or changes in practices) has a significant impact on volatility going forward. We do not examine stock return volatility contemporaneous with disclosure quality and institutional ownership to guard against the possibility of any documented association being the result of some exogenous volatility shock that drives changes in institutional ownership and disclosure.

\section{DATA DESCRIPTION}

The primary variable required for the analysis is a measure of disclosure quality. We measure disclosure quality as the annual ranking of a firm's disclosure published by the Association for Investment and Management Research (AIMR). We have a comprehensive data set for all firms rated by AIMR between 1982 and 1996, resulting in a sample of 4,314 firm-year 
observations (after we ensure the availability of other variables necessary for the analysis). The AIMR rankings capture analysts' assessments of various aspects of firms' disclosure practices and have been used in prior research to proxy for overall levels of disclosure (Lang and Lundholm [1993, 1996], Welker [1995], Sengupta [1998], Healy, Hutton, and Palepu [1999]). The objective of the AIMR disclosure assessment project is to encourage firms to improve their reporting, disclosure, and management access. The ratings of firms' disclosure practices are undertaken on a yearly basis by industry-specific subcommittees. The committees rank firms' disclosure quality on three dimensions: 1) annual report/10-K disclosures, 2) interim report/10-Q disclosures, and 3) investor relations activities. The reported final scores reflect the consensus of the committee. No individual analyst rankings are disclosed. This policy reduces some of the potential for analysts to bias their assessment of a firm's disclosure practices in order to strengthen individual relations with management (Healy, Hutton, and Palepu [1999]).

One complication of using the AIMR database is that different industries are rated on different scales because the analysts within each industry are only responsible for that industry's rankings. In addition, the raw scales occasionally change over time in the same industry. As a result, raw disclosure scores across industries or across time are not comparable. To address this problem, we follow prior research and convert the raw disclosure scores into the percentile rank within each industry-year (Healy, Hutton, and Palepu [1999]).

Another complication is determining the period for which the disclosure rating applies. We assume that the annual disclosure period covered by an annual AIMR report ends on June 30. For example, we would assume that the AIMR report for 1995-96 reflects disclosure quality

\footnotetext{
${ }^{4}$ An important question concerning these rankings is whether they reflect disclosure per se or other attributes that analysts find desirable (e.g., recent performance). Botosan [1997] constructed a checklist to assess annual report disclosure quality and found that it was positively associated with the AIMR assessment of disclosure quality. This correlation provides some support for the fact that the AIMR scores proxy for quality of disclosure.
} 
for the time period between July 1, 1995 and June 30, 1996. $^{\mathrm{W}}$ We choose this time period because by mid-way through the year, firms will have likely completed every activity (e.g., published their annual reports) that is rated by AIMR. Figure 1 presents a timeline that illustrates this example and shows when our other variables are calculated relative to the disclosure period.

We obtain data on institutional holdings from the Spectrum database, which contains all 13-f filings between 1980 and 1997, to measure institutional holdings for each of the three groups of institutions discussed earlier: transient $\left(\mathrm{TRA}_{t}\right)$, dedicated $\left(\mathrm{DED}_{\mathrm{t}}\right)$, and quasi-indexers $\left(\mathrm{QIX}_{\mathrm{t}}\right)$. Institutions are classified into these three groups using a factor and cluster analysis approach described in Bushee [1998, 1999]. 6 Table 1 describes the mean portfolio characteristics of the three types of institutional investors. Transient institutions have high portfolio turnover (high PTURN factor) and diversified portfolios (low BLOCK factor). Dedicated institutions have low turnover and more concentrated portfolio holdings whereas quasi-indexer institutions have low turnover and diversified holdings. The proportion of institution-years in each group is roughly similar to that reported in Bushee [1998, 1999]. Our measure of stock return volatility $\left(\mathrm{STDRET}_{\mathrm{t}}\right)$ is the log of the standard deviation of daily stock returns, which is used in Sias [1996]. We obtain the daily stock return data from the

\footnotetext{
${ }^{5}$ If the committees do not consider any disclosures after the annual report for a December fiscal-year-end firm, it is possible that some date in April or May would be a better cut-off for the end of the disclosure period. However, we only have institutional holdings data at the end of each calendar quarter (e.g., March 31 and June 30). Thus, using an earlier date is impractical because it would precede the release of the annual report for most firms.

${ }^{6}$ This approach begins with a large number of variables that have been used to describe institutional investor trading behavior and portfolio characteristics. To account for the high degree of multicollinearity among these variables, principal factor analysis is used to generate a small number of common factors that explain the shared variance among the original variables. Institutions are then classified into groups using k-means cluster analysis on the factor scores. Like Bushee [1999], we drop the earnings momentum factor from the cluster analysis because 1) directional trading sensitivity to earnings is not an important theoretical factor in this study and 2) the momentum factor produces time-series instability in the Bushee [1998] classification scheme.
} 
1997 CRSP files. We measure STDRET over annual periods between July 1 and June 30 to correspond to the assumed disclosure period and the institutional ownership variables.

We include a large number of control variables to capture previously documented determinants of disclosure quality, institutional ownership, and stock return volatility. Annual market adjusted returns $\left(\mathrm{MRET}_{\mathrm{t}}\right)$ proxy for firm performance, which has been shown to be positively associated with changes in institutional ownership, disclosure quality, and stock return volatility (Lang and McNichols [1997], Lang and Lundholm [1993], Sias [1996]). The level of trading volume in the stock $\left(\mathrm{TVOL}_{\mathrm{t}}\right)$, measured as the average monthly volume over the year divided by average shares outstanding, controls for institutional investor preferences for more liquid stocks (Gompers and Metrick [1998], Falkenstein [1996], Eames [1998]). Firm size, measured as the log of market value $\left(\mathrm{MV}_{\mathrm{t}}\right)$, captures differences in institutional ownership and stock return volatility between small and large firms (Gompers and Metrick [1998], Eames [1998], Sias [1996]). An indicator variable for whether the firm is listed on the S\&P 500 $\left(\mathrm{S} \& \mathrm{P} 500_{\mathrm{t}}\right)$ is included to measure preferences by institutions for firms listed on this index (Bushee [1999]).

We include beta $\left(\right.$ BETA $\left._{t}\right)$, calculated from a market model using daily stock returns over an annual period, idiosyncratic risk $\left(\mathrm{IRISK}_{\mathrm{t}}\right)$, measured as the standard deviation of market model residuals over an annual period, and leverage $\left(\mathrm{LEV}_{\mathrm{t}}\right)$, measured as debt-to-assets, to proxy for various dimensions of firm risk. Higher levels of systematic risk and leverage are generally associated with higher levels of institutional ownership and greater stock return volatility (Badrinath, Gay, and Kale [1989], Skinner [1989]). Higher levels of idiosyncratic risk are generally associated with lower levels of institutional ownership (Bushee [1999]). We also include a number of variables to capture changes in fundamental growth and income ratios upon

\footnotetext{
${ }^{7}$ We require at least 125 nonmissing daily return observations during the year in calculating the standard deviation.
} 
which institutions might base their trading decisions (Bushee [1999], Gompers and Metrick [1998]). These include dividend yield $\left(\mathrm{DP}_{t}\right)$, the earnings-price ratio $\left(\mathrm{EP}_{t}\right)$, the book-price ratio $\left(\mathrm{BP}_{\mathrm{t}}\right)$, and sales growth $\left(\mathrm{SGR}_{\mathrm{t}}\right)$. Finally, we control for the $\mathrm{S} \& \mathrm{P}$ stock rating $\left(\mathrm{RATE}_{\mathrm{t}}\right)$, which is a measure of the prudence of the investment for the institution, because some institutions avoid stocks with lower ratings due to fiduciary concerns (Badrinath, Gay, and Kale [1989], Del Guercio [1996]). All of the control variables are measured for a given year at the points in time indicated in figure 1 using data from the 1997 Compustat and CRSP data files.

Table 2 provides descriptive statistics for all of the variables used in the empirical tests. Because we use an industry rank for our disclosure quality measure, we adopt the approach of prior research and adjust all other variables by the industry mean in the empirical tests (Lang and Lundholm [1993], Healy, Hutton, and Palepu [1999]). However, for ease of interpretation, we present statistics on the unadjusted variables in this table. We also windsorize the extreme $1 \%$ of all variables, except for disclosure and ownership variables, to reduce the impact of outliers. Panel A presents the variables used in the levels tests. After removing observations due to missing data, we have a sample mean and median disclosure rank slightly above 50\%. The table also indicates that firms rated by AIMR tend to be larger, low risk, value firms, with $63 \%$ of the sample listed on the S\&P 500 Index. Summing the holdings by the three types of institutional investors, the average percentage of total institutional ownership is much higher than that reported in prior studies (Bushee [1998, 1999]). This finding is likely due to the fact that institutions invest more heavily in larger, low risk firms (Gompers and Metrick [1998]).

Panel B of table 2 presents variables used in the changes tests. The yearly changes in disclosure are mostly clustered around zero, with $50 \%$ of the sample experiencing a disclosure rank change of less than 12 percentage points. The changes in dedicated $\left(\Delta \mathrm{DED}_{\mathrm{t}}\right)$ and quasi- 
indexer $\left(\Delta \mathrm{QIX} \mathrm{t}_{\mathrm{t}}\right)$ ownership are significantly greater than zero even though we control for time-

series changes in institutional ownership. ${ }^{8}$ This significant difference again likely arises from the fact that firms rated by AIMR and have size, growth, and risk attributes that are attractive to institutions.

\section{DOES DISCLOSURE QUALITY AFFECT INSTITUTIONAL OWNERSHIP?}

\subsection{Levels of disclosure and institutional ownership}

To test whether the percentage of institutional investor ownership by each type is associated with the level of a firm's disclosure quality, controlling for other variables that explain the level of institutional ownership, we estimate the following regression:

$$
\begin{aligned}
\text { INST }_{t}= & \alpha+\beta_{1} \text { DISC }_{t}+\beta_{2} \text { MRET }_{t}+\beta_{3} \text { TVOL }_{t}+\beta_{4} \text { MV }_{t}+\beta_{5} \text { BETA }_{t}+\beta_{6} \text { IRISK }_{t}+ \\
& \beta_{7} \text { LEV }_{t}+\beta_{8} \text { EP }_{t}+\beta_{9} \text { BP }_{t}+\beta_{10} \text { DP }_{t}+\beta_{11} \text { SGR }_{t}+\beta_{12} \text { RATE }_{t}+\beta_{13} \text { SP500 }_{t}+\varepsilon_{t}
\end{aligned}
$$

where INST represents TRA, DED, or QIX

To remove the effects of cross-section correlation inherent in panel data, we adopt a "Fama-Macbeth" approach to estimating eq. (1) and all subsequent regression analyses (Bernard [1987]). This procedure involves two steps. First, the regression model in eq. (1) is estimated separately for each of the fifteen years of data in our sample. Next, the coefficients from each of these regressions are averaged across all years. These average values are then reported along

\footnotetext{
${ }^{8}$ Because prior work has documented significant time trends in institutional ownership (e.g. Gompers and Metrick [1998]), we subtract the mean change in average institutional ownership in the economy for a given type of institution from the change in a firm's institutional ownership by that type to obtain the variables shown in table 2. ${ }^{9}$ All of the pairwise correlations among the control variables in panel B are less than 0.30 (except for the correlation between $\Delta \mathrm{MV}_{\mathrm{t}}$ and $\Delta \mathrm{MAR}_{\mathrm{t}}$ ), whereas there are numerous large pairwise correlations among the levels variables in panel A (not reported). To test for the influence of multicollinearity in our tests, we performed variance inflation factor tests for each regression. Kennedy [1992] cites a VIF score of ten as the benchmark for serious multicollinearity problems. None of the VIF's was above 2.1, indicating that multicollinearity is not likely to significantly influence our results.
} 
with a significance test based on the sample standard deviation of the individual coefficient estimates. 10

Table 3 presents the results of this analysis. Consistent with our predictions, the levels of ownership by both transient institutions (TRA) and quasi-indexer institutions (QIX) are significantly positively associated with the level of disclosure quality. exhibit similar sensitivity to the level of disclosure, the control variables show that the classification is discriminating between two very different types of institutions. Transient institutions prefer firms with recent good stock market performance, suggesting returnmomentum trading strategies, and firms with higher betas, low dividend yields, and high sales growth, all of which are consistent with preferences for riskier growth firms. In contrast, quasiindexers prefer firms with recent poor market performance and high book-to-market ratios, consistent with contrarian value strategies, and firms with high stock ratings listed on the S\&P 500, indicating concerns about fiduciary responsibility. Both types prefer larger firms with less idiosyncratic risk and higher levels of trading volume. The latter finding suggests that quasiindexers are also concerned about liquidity.

The level of dedicated ownership is unrelated to the level of disclosure quality, consistent with our arguments that this type of institution does not value the benefits of high disclosure

\footnotetext{
${ }^{10}$ This procedure for calculating standard errors assumes there is no serial correlation in the coefficients across time. We also calculated standard errors using an adjustment for serial correlation provided in Abarbanell and Bernard [Forthcoming]. This adjustment produced no meaningful differences in significance levels for the disclosure quality variable as the first-order autocorrelation in yearly coefficients was less than 0.28 in each regression.

${ }^{11}$ Not surprisingly, the overall level of institutional ownership (not reported) is significantly associated with the level of disclosure as well, confirming the results of Healy, Hutton, and Palepu [1999].

${ }^{12} \mathrm{We}$ also performed the empirical tests on the separate scores for each dimension of disclosure quality (not reported). For approximately half of our sample firms, the ratings committees provide separate rankings of the quality of 1) annual report disclosures, 2) interim report disclosures, and 3) investor relations activities. We find that transient ownership is significantly positively related to the quality of interim report disclosures and to investor relations quality but unrelated to the quality of annual report disclosures, suggesting that transient investors are sensitive to more timely information released throughout the year. Quasi-indexer ownership is significantly positively related to the quality of both annual and interim report disclosures, and unrelated to investor relations
} 
quality. Very few of the control variables explain dedicated preferences for stocks and the average $\mathrm{R}^{2}$ is less than $5 \%$, which is consistent with the results in Bushee [1999]. Dedicated institutions tend to invest in value firms with high book-to-price ratios that pay low dividends and have low stock ratings, indicating a strategy of investing in underperforming firms with the intention of creating value by helping to turn around the company.

\subsection{Changes in disclosure quality and institutional ownership}

The prior section documents strong associations between disclosure quality and institutional ownership. To test the robustness of this result, we next test whether year-to-year changes in a firm's disclosure quality lead to significant rebalancing of institutional investor holdings. This test also sheds light on how quickly different types of institutions respond to disclosure changes. We take first differences in the eq. (1) specification, with some slight modifications, to obtain the following regression:

$$
\begin{aligned}
\Delta \text { INST }_{\mathrm{t}}= & \alpha+\beta_{1} \Delta \mathrm{DISC}_{\mathrm{t}}+\beta_{2} \Delta \text { DISC }_{\mathrm{t}} * \mathrm{DNDISC}_{\mathrm{t}}+\beta_{3} \text { QDISC }_{\mathrm{t}-1}+\beta_{4} \text { QINST }_{\mathrm{t}-1}+ \\
& \beta_{5} \Delta \mathrm{MRET}_{\mathrm{t}}+\beta_{6} \mathrm{TVOL}_{\mathrm{t}-1}+\beta_{7} \Delta \mathrm{MV}_{\mathrm{t}}+\beta_{8} \text { BETA }_{\mathrm{t}-1}+\beta_{9} \mathrm{IRISK}_{\mathrm{t}-1}+ \\
& \beta_{10} \Delta \mathrm{LEV}_{\mathrm{t}}+\beta_{11} \Delta \mathrm{EP}_{\mathrm{t}}+\beta_{12} \Delta \mathrm{BP}_{\mathrm{t}}+\beta_{13} \Delta \mathrm{DP}_{\mathrm{t}}+ \\
& \beta_{14} \Delta \mathrm{SGR}_{\mathrm{t}}+\beta_{15} \Delta \mathrm{RATE}_{\mathrm{t}}+\beta_{16} \Delta \mathrm{SHRS}_{\mathrm{t}}+\varepsilon_{\mathrm{t}}
\end{aligned}
$$

where INST represents TRA, DED, or QIX

We calculate the annual change in disclosure quality $\left(\Delta \mathrm{DISC}_{\mathrm{t}}\right)$ as the difference between rankings in two adjacent years (see figure 1). ${ }^{1.3}$ We interact this variable with an indicator variable for decreases in disclosure quality (DNDISC $\mathrm{D}_{\mathrm{t}}$ ) to test for any asymmetry in responses to

quality. This result implies that this type of institution relies on mandatory reports rather than investor relations to monitor firm performance, consistent with their fragmented ownership positions.

${ }^{13}$ To mitigate concerns that the change in disclosure ranking is due to some factor other than actual disclosure changes (e.g., market performance), we read the analyst comments in the AIMR disclosure reports. In almost every case, the analysts comment on the sources of big changes in disclosure, citing factors such as changes in annual report detail (e.g., segment information, MD\&A quality) and in access to management. The fact that changes in AIMR scores represent real changes in firms' disclosure practices is also supported by the analysis in Healy, Hutton, and Palepu [1999]. 
disclosure quality increases and decreases. Also, because many firms have little or no change in yearly disclosure ranking, we include the prior level of disclosure in the regression to test whether institutions are attracted to firms with higher prior levels of disclosure. We control for the prior level of institutional ownership by each type to capture the fact the firms with small institutional investor bases are likely to experience larger changes in ownership. To prevent a mechanical association between the prior levels of disclosure quality/institutional ownership and the changes in those variables, we use the quintile ranking of the prior levels in the regression specification. These variables are identified as QDISC $_{\mathrm{t}-1}$ and $\mathrm{QINST}_{\mathrm{t}-1}$. We use the prior year's level of liquidity, beta, and idiosyncratic risk rather than the contemporaneous changes in those variables because those changes are potentially endogenous with changes in institutional ownership (Eames [1998]). ${ }^{14}$ We drop the S\&P500 ${ }_{\mathrm{t}}$ variable because there are few yearly instances of changes in S\&P 500 Index status. Finally, we add the absolute value of the change in log shares outstanding $\left(\Delta \mathrm{SHRS}_{\mathrm{t}}\right)$ to proxy for any stock issuances or repurchases during the year that might trigger significant disclosure quality and/or institutional ownership changes.

Table 4 presents the findings of this analysis. Transient institutions significantly increase their holdings in firms that improve disclosure quality but do not significantly change their holdings based on disclosure quality reductions. These results suggest that transient institutions are attracted to firms that improve their liquidity by improving disclosure quality but do not immediately sell out of firms merely because their disclosure quality drops. Transient institutions also tend to increase their holdings in firms with higher levels of disclosure, although this association is weak ( $p$-value $=0.108)$.

\footnotetext{
${ }^{14}$ However, all of our main results are quantitatively similar when the contemporaneous changes in liquidity, beta, and idiosyncratic risk are used.
} 
Quasi-indexers are also sensitive to changes in disclosure but only when disclosure quality is reduced. The positive coefficient on $\Delta \mathrm{DISC}_{\mathrm{t}} * \mathrm{DNDISC}_{\mathrm{t}}$ indicates that quasi-indexers decrease their holdings in firms with decreases in disclosure quality, suggesting that such decreases impair these institutions' ability to monitor firm performance cost-effectively and, hence, trigger a significant reduction in their investment in the firm. Quasi-indexers do not tend to increase their holdings in firms with improvements in disclosure quality, but they do invest more heavily in firms that have high prior levels of disclosure, indicating that quasi-indexers respond to disclosure improvements, albeit more slowly than transient institutions.

Finally, consistent with the levels results, there are no significant associations between changes in dedicated institutional ownership and disclosure quality changes. Both sets of results imply that the large, stable ownership positions of dedicated institutions likely provide them direct channels of information from firms and lessen concerns about the benefits of high quality disclosure.

Although we argue that our results indicate that institutional investors react to disclosure levels and changes, it is difficult to prove causality using our approach. Our findings would also be consistent with managers increasing disclosure quality in response to exogenous changes in the composition of their institutional investor base. While this may be plausible with quasiindexer institutions, which might demand higher-quality disclosure to facilitate monitoring, it is unlikely that managers would respond to demands of transient institutions. It is also possible that disclosure quality changes and institutional investor changes are both driven by some omitted factor. This alternative explanation is impossible to dismiss. However, our extensive set of control variables limits the likelihood that the documented relation stems from some unknown omitted factor and the consistency in results between levels and changes tests increases our 
confidence that the results indicate institutional investors are reacting to the benefits of improved disclosure quality. 15

\section{DO DISCLOSURE QUALITY AND INSTITUTIONAL OWNERSHIP AFFECT SUBSEQUENT STOCK RETURN VOLATILITY?}

\subsection{Levels of volatility}

To test whether disclosure quality and the level of ownership by different types of institutional investors have any consequences for subsequent stock return volatility, we modify eq. (1) to obtain the following regression:

$$
\begin{aligned}
\text { STDRET }_{\mathrm{t}+1}= & \alpha+\beta_{1} \text { DISC }_{\mathrm{t}}+\beta_{2} \text { TRA }_{\mathrm{t}}+\beta_{3} \mathrm{DED}_{\mathrm{t}}+\beta_{4} \mathrm{QIX}_{\mathrm{t}}+\beta_{5} \text { MRET }_{\mathrm{t}}+\beta_{6} \text { TVOL }_{\mathrm{t}}+ \\
& \beta_{7} \mathrm{MV}_{\mathrm{t}}+\beta_{8} \mathrm{LEV}_{\mathrm{t}}+\beta_{9} \mathrm{EP}_{\mathrm{t}}+\beta_{10} \mathrm{BP}_{\mathrm{t}}+\beta_{11} \mathrm{DP}_{\mathrm{t}}+\beta_{12} \mathrm{SGR}_{\mathrm{t}}+ \\
& \beta_{13} \text { RATE }_{\mathrm{t}}+\beta_{43} \mathrm{SP} \mathrm{SOO}_{\mathrm{t}}+\varepsilon_{\mathrm{t}}
\end{aligned}
$$

We use control variables that are contemporaneous with the disclosure quality and institutional ownership variables, rather than contemporaneous with stock return volatility, because we are more concerned about controlling for factors that drive future volatility and are correlated with disclosure and institutional ownership than we are in trying to maximize explanatory power in the volatility regression. We do not include the prior level of volatility $\left(\mathrm{STDRET}_{\mathrm{t}}\right)$ or its components (beta and idiosyncratic risk) in this regression so that our variables are explaining the level of volatility rather than the change in volatility. 16

\footnotetext{
${ }^{15}$ One potential omitted variable is analyst following, which may be correlated with both the disclosure quality score and institutional ownership. Including this variable is problematic because the level of institutional ownership and analyst following are simultaneously determined (O'Brien and Bhushan [1990]). We included the number of analysts as an additional control variable and found that the level of analyst following is significantly associated with the level of transient and quasi-indexer ownership and that changes in analyst following are unrelated to changes in institutional ownership. Including analyst following did not materially change the significance of the disclosure quality coefficient in either regression (in fact, the coefficient magnitudes were virtually identical). Thus, our main results are not sensitive to the inclusion of an analyst following variable.

${ }^{16}$ Because we use the Fama-McBeth methodology to estimate this regression, we do not need to control for marketwide volatility because this variable would be a constant across all firms in each yearly regression.
} 
We first estimate eq. (3) with only the level of disclosure quality and the control variables as regressors. The first column of table 5 reveals that the level of disclosure quality is negatively associated with future stock return volatility with a marginally significant $p$-value of 0.06 . Thus, there is some evidence that firms that provide higher quality disclosures experience lower future stock market volatility, controlling for other factors that affect volatility. Table 5 indicates that such factors include higher trading volume, smaller size, higher leverage, lower dividend yield and earnings-price ratios (growth firms), higher book-to-market ratios (potentially undervalued firms) and lower stock ratings.

The second column of table 5 contains a regression specification that includes only the level of institutional ownership by the various types of institutions along with the control variables. The second column of table 5 reveals that higher levels of transient ownership lead to higher future stock return volatility, whereas higher levels of quasi-indexer and dedicated ownership contribute to lower levels of future volatility. These results are not surprising given the propensity of transient institutions to trade actively based on short-term news while dedicated and quasi-indexer institutions tend to hold stocks for longer horizons. The coefficient on TRA indicates that $10 \%$ greater transient ownership would increase return volatility by $0.2 \%$, which would represent a $12 \%$ higher level of volatility than the mean volatility of $1.8 \%$. The similar effect for $10 \%$ greater quasi-indexer ownership would be a $4 \%$ reduction in volatility relative to the mean. Thus, these coefficients indicate an effect that is likely to be economically significant. Combined with table 3 , the results in table 5 indicate that disclosure quality has a positive indirect effect on stock return volatility through the attraction of transient institutions and a negative indirect effect on volatility through the attraction of higher quasi-indexer ownership. To sort out the magnitudes of the direct and indirect effects of disclosure quality on stock return 
volatility, we estimate eq. (3), which contains both disclosure and institutional ownership variables. The magnitudes and significance levels of the coefficients are similar to the regressions that separately contain disclosure and ownership variables.

Figure 2 uses a path analysis diagram to provide further insight into the direct and indirect effects of disclosure quality on stock return volatility (Pedhazur [1982]). To construct this figure, we first standardize the average regression coefficients from tables 3 and 5 to make effect sizes comparable across tables and between regressors. ${ }^{17}$ Next, we multiply the standardized coefficient estimate of the impact of disclosure quality on transient ownership from table 3 by the standardized estimate of the impact of transient ownership on future stock return volatility from table 5 to obtain the indirect effect of disclosure quality on future volatility through transient ownership. We repeat this procedure for the other types of institutional ownership. The direct effect of disclosure on stock return volatility is the standardized coefficient on DISC $_{\mathrm{t}}$ from column 3 of table 5. Figure 2 indicates that the negative indirect effect on stock return volatility of attracting quasi-indexers almost completely offsets the positive indirect volatility effect of attracting transient ownership. Thus, firms with high disclosure quality experience relatively lower stock return volatility as long as they attract both quasiindexer and transient institutions. 18

\subsection{Changes in volatility}

The prior section indicates that the link between disclosure quality and the composition of a firm's institutional ownership has no net effect on future stock return volatility. However,

\footnotetext{
${ }^{17}$ Average coefficients are standardized by dividing the coefficient by the ratio of the standard deviation of the dependent variable to the standard deviation of the regressor.

${ }^{18}$ As a robustness check, we verified all of our results using an alternative measure of future stock return volatility. This measure adjusts for daily autocorrelations in returns caused by nonsynchronous trading and is calculated as the square root of the sum of squared daily returns plus twice the sum of the product of adjacent daily returns (French, Schwert, and Stambaugh [1987]). Because nonsynchronous trading is likely to be a more significant problem in
} 
because transient and quasi-indexers have asymmetric responses to disclosure changes, as documented in table 4, it is interesting to test how the disclosure-ownership link affects future stock return volatility when disclosure policies are changed. To test whether changes in institutional holdings have any consequences for future stock return volatility around the times when firms change their disclosure quality, we take first differences of eq. (3) to obtain the following regression:

$$
\begin{aligned}
\Delta \text { STDRET }_{\mathrm{t}+1}= & \alpha+\beta_{1} \Delta \mathrm{DISC}_{\mathrm{t}}++\beta_{2} \Delta \mathrm{DISC}_{\mathrm{t}} * \mathrm{DNDISC}+\beta_{3} \Delta \mathrm{TRA}_{\mathrm{t}}+\beta_{4} \Delta \mathrm{DED}_{\mathrm{t}}+ \\
& \beta_{5} \Delta \mathrm{QIX}_{\mathrm{t}}+\beta_{6} \Delta \mathrm{MRET}_{\mathrm{t}}+\beta_{7} \Delta \mathrm{TVOL}_{\mathrm{t}}+\beta_{8} \Delta \mathrm{MV}_{\mathrm{t}}+\beta_{9} \Delta \mathrm{LEV}_{\mathrm{t}}+\beta_{10} \Delta \mathrm{EP}_{\mathrm{t}}+ \\
& \beta_{11} \Delta \mathrm{BP}_{\mathrm{t}}+\beta_{12} \Delta \mathrm{DP}_{\mathrm{t}}+\beta_{13} \Delta \mathrm{SGR}_{\mathrm{t}}+\beta_{14} \Delta \mathrm{RATE}_{\mathrm{t}}+\beta_{15} \Delta \mathrm{SHRS}_{\mathrm{t}}+\varepsilon_{\mathrm{t}}
\end{aligned}
$$

Once again, we allow the coefficient on disclosure changes to differ for increases and decreases in quality, and we replace the S\&P 500 Index indicator with the absolute value of change in shares outstanding to control for significant equity transactions.

The first column in table 6 presents results of estimating eq. (4) with only the change in disclosure variables as well as the controls. The coefficient on $\Delta \mathrm{DISC}_{\mathrm{t}}$ is positive, indicating that improvements in disclosure actually lead to increases in stock return volatility, but it is not significant at conventional levels $(p$-value $=0.137)$. The results also indicate that reductions in disclosure quality have no significant impact on future changes in stock return volatility. The control variables in this regression have consistent signs and significance levels with the analysis in table 5 except for the change in trading volume, which is negatively associated with future changes in stock return volatility. This result is likely due to mean reversion in the volume variable that leads to a subsequent drop in stock return volatility relative to the base year. The 
$\Delta \mathrm{SHRS}_{\mathrm{t}}$ variable is significantly positive, indicating that significant equity transactions result in relatively more positive changes in future stock return volatility.

The second column of table 6 present results of a regression only including the ownership variables along with the controls. The coefficient on $\Delta \mathrm{TRA}_{\mathrm{t}}$ is positive and significant, indicating that increases in the presence of transient ownership lead to significant increases in stock return volatility. This result is consistent with the levels analysis presented in table 5 . However, changes in dedicated or quasi-indexer ownership have no significant impacts on changes in future stock return volatility. These results suggest that the dampening effect on stock return volatility of infrequent trading by quasi-indexer and dedicated institutions is not as strong of an effect as the creation of volatility by transient institutions that aggressively trade in a stock.

The final column presents results of the full eq. (4), allowing a comparison of direct and indirect effects of disclosure quality changes on changes in stock return volatility. Including the changes in disclosure quality variable does not greatly change the coefficients on the institutional ownership variables. However, controlling for changes in institutional ownership yields a positive direct effect of increased disclosure on future changes in future stock return volatility that is marginally significant $(p$-value $=0.095)$. This result is consistent with Lang and Lundholm [1993], who document a positive association between levels of disclosure and levels of stock return volatility. If we control for future changes in disclosure (not reported), current increases in disclosure no longer significantly explain future changes in stock return volatility while the significance of changes in transient ownership is unaffected. Thus, the positive 
association between changes in disclosure quality and future changes in stock return volatility is likely driven by mean reversion in extreme disclosure changes. 19

Figure 3 presents a path diagram that allows a comparison of the magnitude of the direct and indirect effects of changes in disclosure quality on future changes in stock return volatility. The direct effect of disclosure improvements on future changes in stock return volatility, though only marginally statistically significant, is much larger in magnitude than the statistically significant indirect effect of disclosure improvements on volatility through increases in transient ownership. However, the significant indirect effect of disclosure changes on future changes in stock return volatility through attracting transient institutions is much larger in magnitude than the other indirect effects. This finding suggests that the offsetting indirect effects observed in the levels analysis from table 5 do not carry over to the changes specification in table 6 . This result is due to the asymmetric responses of transient and quasi-indexer institutions to disclosure changes and to the much larger impact on stock return volatility of changes in transient ownership. Thus, managers making significant improvements in disclosure quality are likely to experience an increase in stock return volatility due to the attraction of transient ownership that is not immediately offset by an increase in quasi-indexer or dedicated ownership.

\subsection{Sensitivity analyses}

We examined other forms of stock return volatility that might be more important to managers than the standard deviation of stock returns over a given year. First, we tested the impact of disclosure quality and institutional ownership on stock return volatility around earnings announcements. We replaced the annual volatility variables with the stock return volatility in the five days surrounding quarterly earnings announcements and repeated the

\footnotetext{
${ }^{19}$ As an example of such a reversal, Paine Webber had scored a large increase in 1992 due to improvements in the Chairman's letter and management accessibility. In 1993, Paine Webber's score dropped significantly due to a
} 
analysis in tables 5 and 6 (not reported). The levels results produced the same significant associations between disclosure quality, transient ownership, quasi-indexer ownership, and stock return volatility as in the table 5 regression. In this changes analysis, the key variables were consistent in sign with the table 6 regression but not statistically significant at conventional levels. Thus, there is some evidence that our findings apply to stock return volatility around earnings announcements when looking at levels of disclosure and institutional ownership. 20

Second, we examined the frequency of "big" one-day stock price increases or decreases. Managers might be concerned about the frequency of large one-day drops in price because such drops are frequently cited as the trigger for securities lawsuits (Lang and Lundholm [1993]). We calculated the percentage of trading days in a given year in which the firm's stock price dropped or increased by more than $1 \%$ and by more than $5 \%$. We repeated the table 5 and 6 analyses using the level of and change in these percentages (not reported). Both the levels and changes results were of similar sign and significance when the dependent variable was number of days with $1 \%$ price changes and number of days with $1 \%$ price declines. When we looked at the number of days with greater than $5 \%$ price changes and declines, only the $\mathrm{TRA}_{t}$ and $\Delta \mathrm{TRA}_{\mathrm{t}}$ variables were significant in the levels and changes specifications, respectively, while the disclosure variables lose their significance. Overall, these results indicate that the indirect effect of disclosure on stock return volatility through transient ownership applies to other measures of volatility that might be more salient to managers, namely volatility around earnings announcements and the number of days with large stock price changes.

\footnotetext{
"meaningful decline" in the discussion of their financial results.

${ }^{20}$ We also measured earnings announcement volatility using a "U-statistic," which is the ratio of stock return volatility in earnings announcement periods to volatility in non-announcement periods (Patell [1976], Potter [1992], El-Gazzar [1998]). The results using this variable are of the expected sign but insignificant, indicating that the distribution of stock return volatility during the year does not significantly change as disclosure and institutional ownership change.
} 


\section{CONCLUSIONS}

This paper provides new evidence on the impact of a firm's disclosure practices on the composition of its institutional investor base and the volatility of its stock price. Our findings support prior work by Healy, Hutton, and Palepu [1999] in showing that institutional investors are attracted to firms with high-quality disclosure practices. Further examination of the characteristics of institutional investors that tend to be attracted to firms with high disclosure quality reveals that two very different types of institutions value high-quality disclosure. One type of institution attracted to good disclosure practices, quasi-indexers, exhibits long investment horizons and low portfolio turnover. Attracting this type of institution helps reduce the volatility of a firm's stock price. However, high-quality disclosure also attracts transient institutions, which appear to exacerbate a firm's stock return volatility with their short investment horizons and aggressive trading strategies.

We show that the net effect on stock return volatility of having both of these types of institutions own shares in a firm is roughly zero. However, when firms improve the quality of their disclosure practices, transient institutions immediately increase their holdings, whereas quasi-indexers do not, leading to a significant increase in firms' stock return volatility. Thus, this paper has important implications for firms contemplating changes in their disclosure practices. Specifically, managers faced with decisions about whether to change their firms' disclosure practices must weigh any potential benefits of improved disclosure quality against the potential cost of attracting investors that exacerbate stock price volatility. 


\section{REFERENCES}

Abarbanell, J. and V. Bernard. Forthcoming. Is the U.S. stock market myopic? Journal of Accounting Research

Anand, V. 1991. Big and small companies are marketing their stock. Investor's Daily (January 25): 8.

Badrinath, S., G. Gay, and J. Kale. 1989. Patterns of institutional investment, prudence, and the managerial "safety-net" hypothesis. Journal of Risk and Insurance 56 (December): 605629.

Baiman, S. and R. Verrecchia. 1995. Earnings and price-based compensation contracts in the presence of discretionary trading and incomplete contracting. Journal of Accounting and Economics 20 (July): 93-121.

Bernard, V. 1987. Cross-sectional dependence and problems in inference in market-based accounting research. Journal of Accounting Research (Spring): 1-48.

Botosan, C. 1997. Disclosure level and the cost of equity capital. Accounting Review 72 (July): 323-349.

Bushee, B., 1998. The influence of institutional investors on myopic R\&D investment behavior. Accounting Review 73 (July): 305-333.

Bushee, B. 1999. Do institutional investors prefer near-term earnings over long-run value? Working paper. University of Chicago.

Bushman, R., Q. Chen, E. Engel, and A. Smith. 1999. The sensitivity of corporate governance systems to the timeliness of accounting earnings. Working paper. University of Chicago.

Byrne, J. 1999 When capital gets antsy. Business Week (September 13): 72-76.

Diamond D. and R. Verrecchia. 1991. Disclosure, liquidity, and the cost of capital. Journal of Finance 66 (September): 1325-1355.

Dobrzynski, J. 1993. Relationship investing. Business Week 3309 (March 15): 68-75.

Del Guercio, D., 1996. The distorting effect of the prudent man law of institutional equity investments. Journal of Financial Economics 40: 31-62.

Eames, M. 1998. Institutional investor myopia, ownership, earnings, and returns. Working paper. Santa Clara University.

El-Gazzar, S. 1998. Predisclosure information and institutional ownership: A cross-sectional examination of market revaluations during earnings announcement periods. Accounting Review 73 (January): 119-130. 
Elgin, P. 1992. Strategic pairings uncork blessings for investors, issuers. Corporate Cashflow 13 (September): 7-8.

Falkenstein, E., 1996. Preferences for stock characteristics as revealed by mutual fund portfolio holdings. Journal of Finance 51 (March): 111-135.

Fox, J., 1997. Learn to play the earnings game (and Wall Street will love you). Fortune (March 31): 76-79.

French, K, G. Schwert, and R. Stambaugh. 1987. Expected stock returns and volatility. Journal of Financial Economics 19 (September): 3-29.

Froot, K., A. Perold, and J. Stein. Shareholder trading practices and corporate investment horizons. Journal of Applied Corporate Finance (Sept/Oct): 42-58.

Froot, K.A., D.S. Scharfstein, and J.C. Stein. 1992. Herd on the street: Informational inefficiencies in a market with short-term speculation. Journal of Finance 47 (September): 1461-84.

Gompers, P. and A. Metrick, 1998. How are large institutions different from other investors? Why do these differences matter? Working paper. Harvard Business School.

Healy P., A. Hutton, and K. Palepu, 1999. Stock performance and intermediation changes surrounding increases in disclosure. Working paper. Harvard Business School.

Jacobs, M. 1991. Short-Term America: The Causes and Cures of Our Business Myopia. Boston, MA: Harvard Business School Press.

Jorgensen, B. 1998. Hedging and performance evaluation. Working Paper. Harvard Business School.

Kennedy, P. 1992. A Guide to Econometrics, 3d ed. Cambridge, MA: The MIT Press.

Kim, O. and R. Verrecchia. 1994. Market liquidity and volume around earnings announcements. Journal of Accounting and Economics 17 (January): 41-67.

Lang, M. and R. Lundholm. 1993. Cross-sectional determinants of analysts ratings of corporate disclosures. Journal of Accounting Research 31 (Autumn): 246-271.

Lang, M. and R. Lundholm. 1996. Corporate disclosure policy and analysts. Accounting Review 71 (October): 467-92.

Lang, M., and M. McNichols. 1997. Institutional trading and corporate performance. Working paper. Stanford University.

Leuz, C. and R. Verrecchia. 1999. The economic consequence of increase disclosure. Working paper. Goethe University. 
Lev, B. 1991. Identifying the preferences of institutional investors and implementing a strategy for change. Working Paper. University of California at Berkeley.

Miller, G. 1999. Do managers let strong earnings performance speak for itself? Working paper. Harvard Business School.

O'Brien, P., and R. Bhushan. 1990. Analyst following and institutional ownership. Journal of Accounting Research 28 (Supplement): 55-76.

Patell, J. 1976. Corporate forecasts of earnings per share and stock price behavior: Empirical tests. Journal of Accounting Research 14 (Autumn): 246-276.

Pedhazur, E. 1982. Multiple Regression in Behavioral Research. New York, NY: Holt, Rinehart, and Winston.

Porter, M. 1992. Capital Choices: Changing the Way America Invests in Industry. Boston, MA: Council on Competitiveness/ Harvard Business School.

Potter, G. 1992. Accounting earnings announcements, institutional investor concentration, and common stock returns. Journal of Accounting Research 30 (Spring): 146-155.

Price, R. 1998. Price responsiveness of informed investors to increases in financial statement disclosure quality. Working Paper. College of William and Mary.

Schonfeld, E. 1998. The guidance game. Fortune (December 21): 267-268.

Sengupta, P. 1998. Corporate disclosure quality and the cost of debt. Accounting Review 73 (October): 459-474.

Serwer, A. 1997. The scariest tech stock ever! The ups and downs of Ascend. Fortune (November 10): 223-224.

Sias, R. 1996. Volatility and the institutional investor. Financial Analysts Journal (March/April): 13-20.

Skinner, D. 1989. Options markets and stock return volatility. Journal of Financial Economics 23: 61-78.

Smith, M. 1996. Shareholder activism by institutional investors: Evidence from CalPERS. Journal of Finance 51 (March): 227-251.

Welker, M. 1995. Disclosure policy, information asymmetry, and liquidity in equity markets. Contemporary Accounting Research 11 (Spring): 801-827. 
FIGURE 1

Timeline Depiction of Empirical Analysis for the 1995-96 AIMR Report

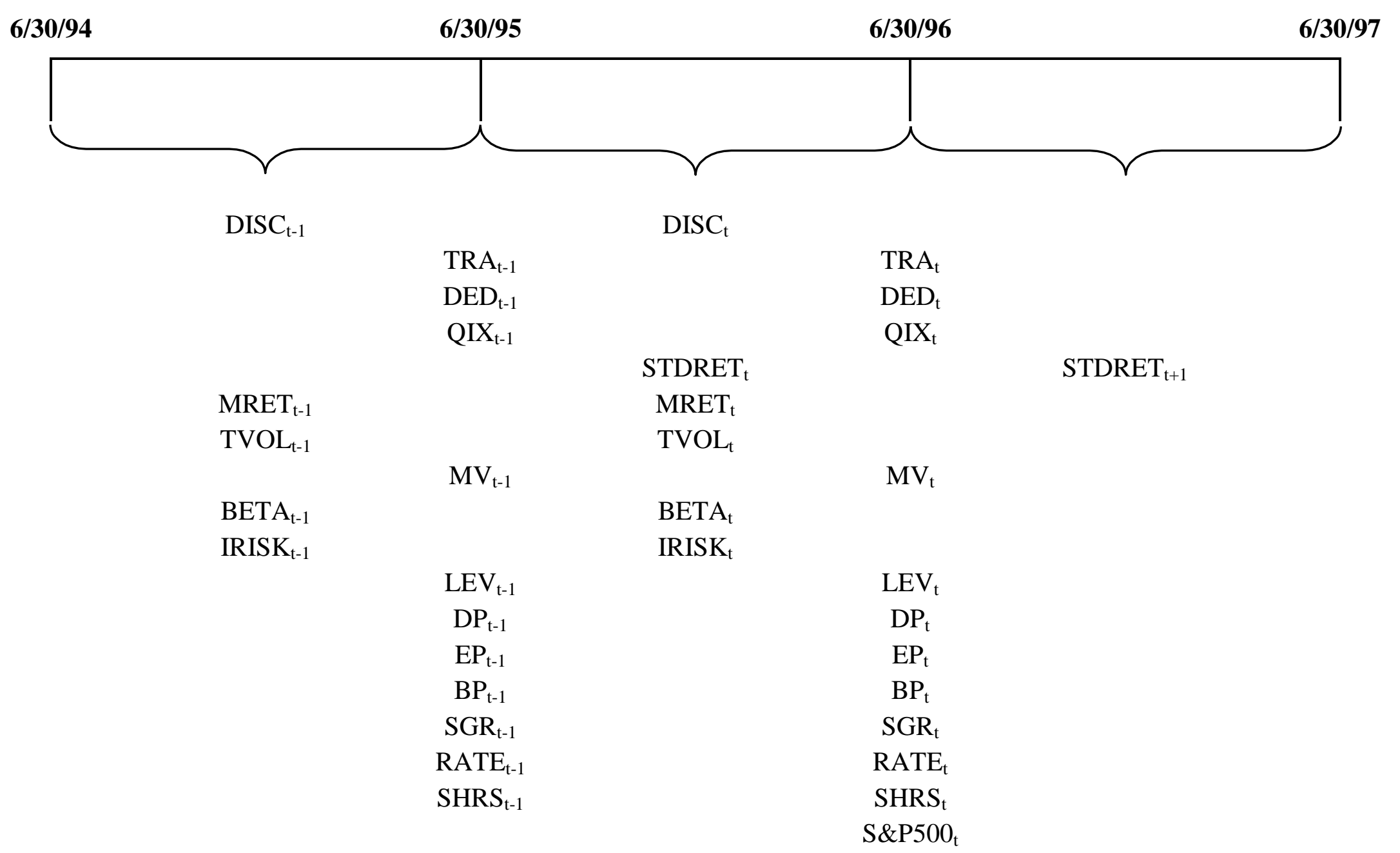


FIGURE 2

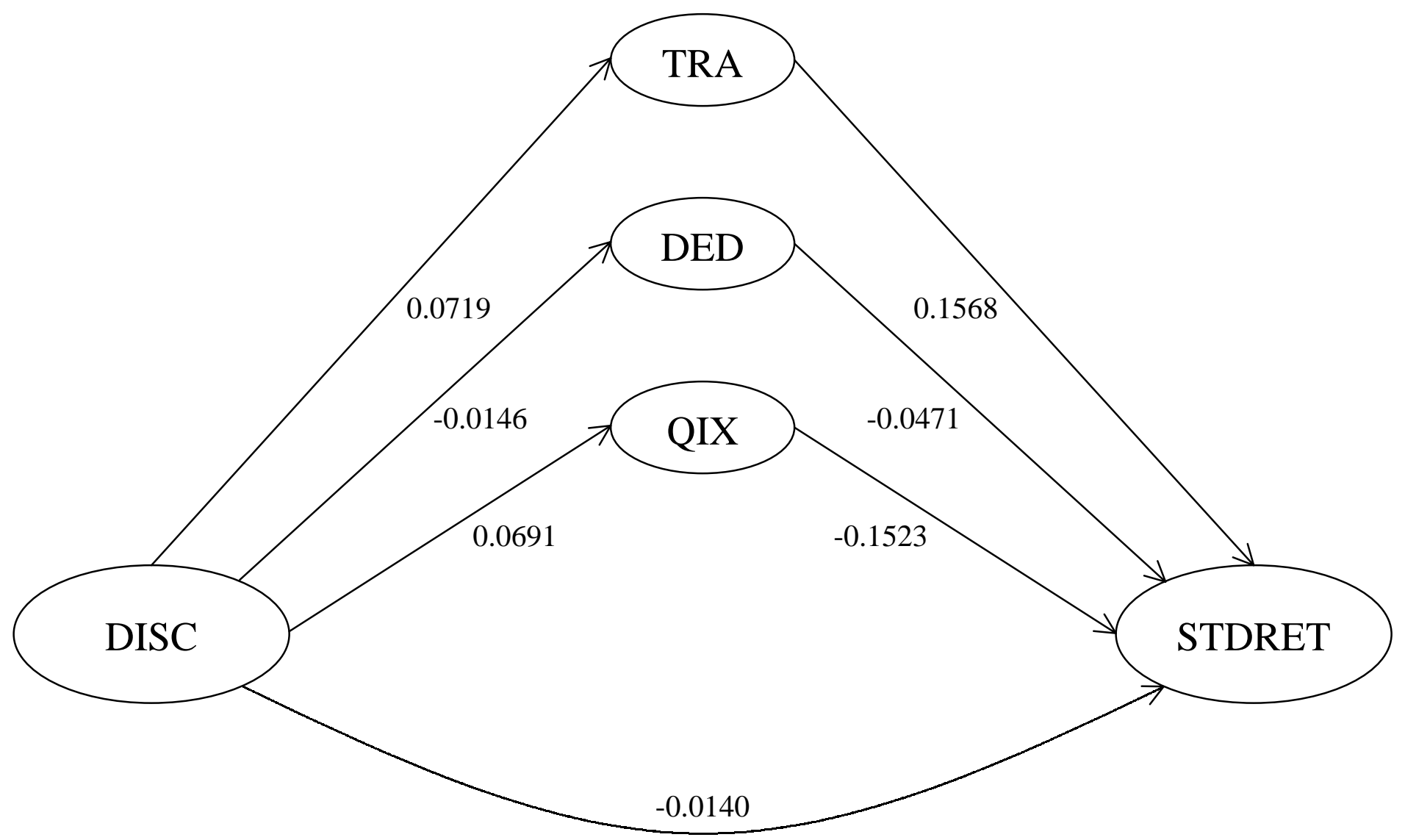

$\mathrm{DISC} \Rightarrow \mathrm{TRA} \Rightarrow \mathrm{STDRET}=0.0113$

$\mathrm{DISC} \Rightarrow \mathrm{DED} \Rightarrow \mathrm{STDRET}=0.0007$

$\mathrm{DISC} \Rightarrow$ QIX $\Rightarrow$ STDRET $=-0.0105$

$\mathrm{DISC} \Rightarrow \mathrm{STDRET}=-0.0140$ 
FIGURE 3

Standardized Coefficients from Changes Regressions

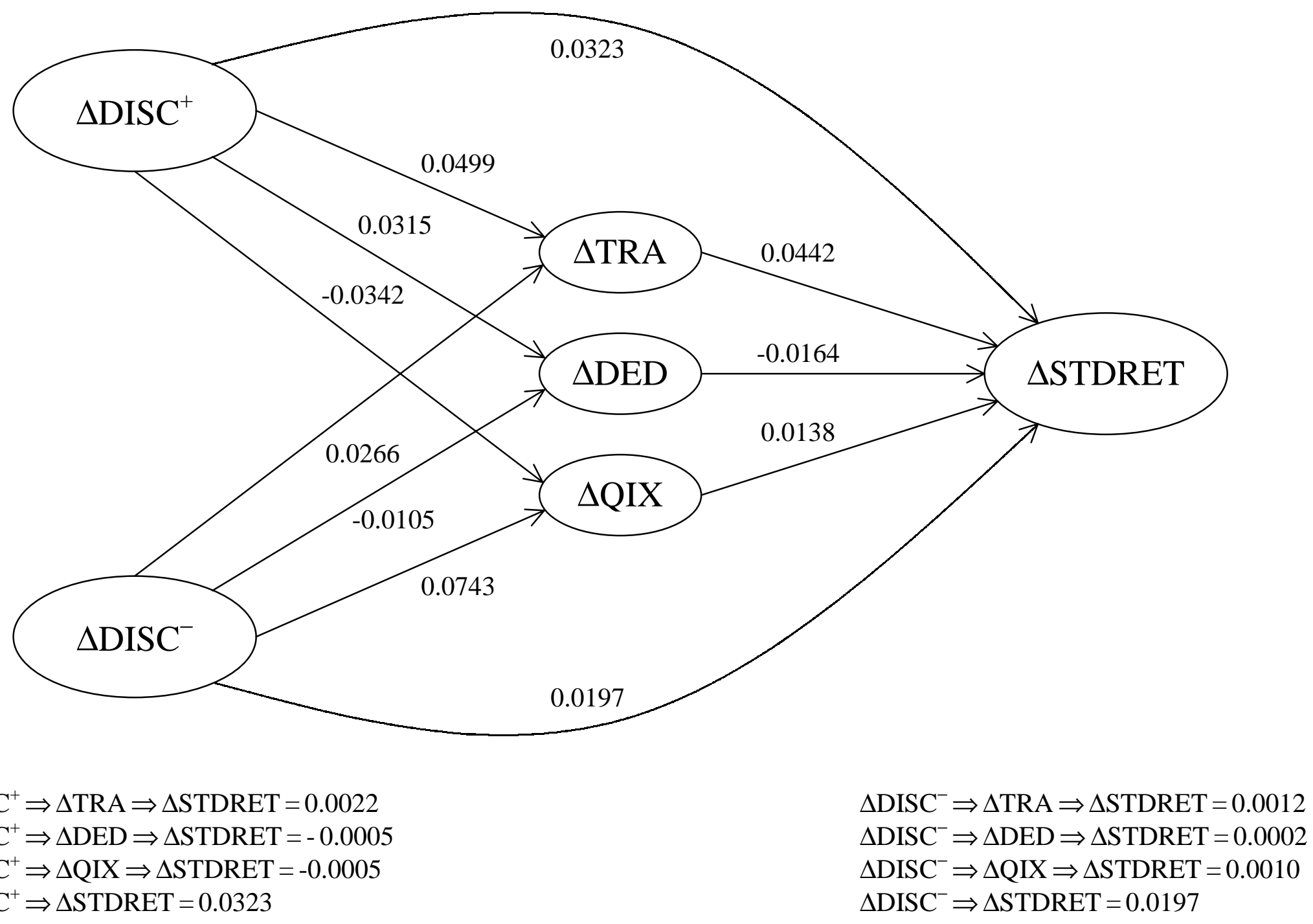


TABLE 1

Portfolio Characteristics of Institutional Investor Groups

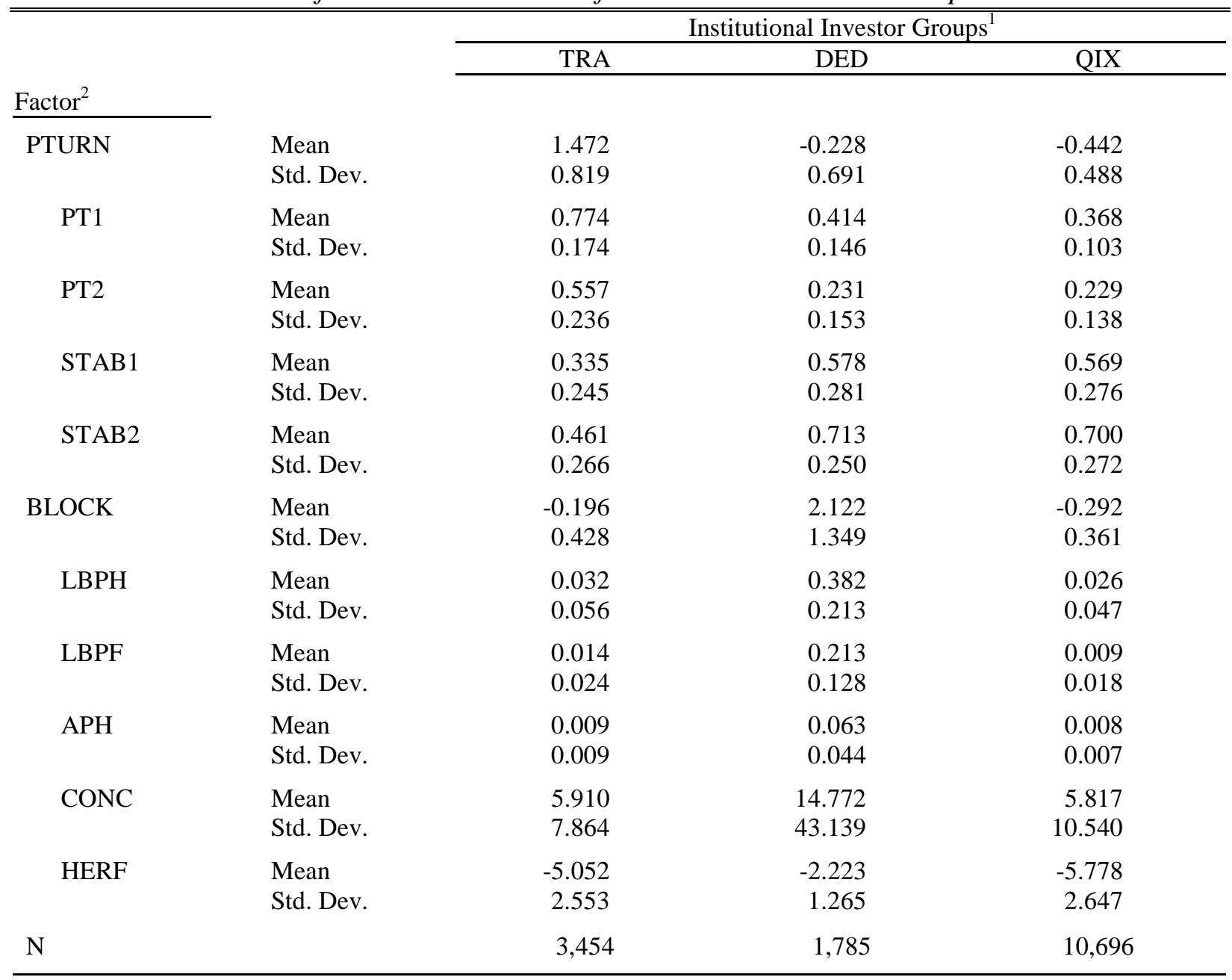

where PTURN = Portfolio Turnover Factor

PT1 = the institution's quarterly portfolio turnover percentage

PT2 $=$ the institution's quarterly portfolio turnover percentage using only sales transactions

STAB1 = the percentage of the institution's holdings held continuously for two years

STAB2 = the percentage of the institution's portfolio firms held continuously for two years

BLOCK $=$ Block Size Factor

LBPH $=$ the percentage of the institution's holdings held in large blocks (greater than a 5\% stake)

$\mathrm{LBPF}=$ the percentage of the institution's portfolio firms held in large blocks (greater than a 5\% stake)

$\mathrm{APH}=$ the institution's average percentage ownership in its portfolio firms

CONC $=$ the institution's average investment size in its portfolio firms (millions \$)

HERF $=$ Herfindahl concentration measure calculated as the natural logarithm of the sum of the squared percentage ownership in each of the institution's portfolio firms

$\mathrm{N}=$ Number of institution-years in group

${ }^{1}$ TRA $=$ transient institutional investors, DED =dedicated institutional investors, and QIX=quasi-indexer institutional investors. Institutions are classified into these groups using the factor and cluster analysis approach described in Bushee [1998, 1999].

${ }^{2}$ The numbers in the rows corresponding to PTURN and BLOCK are factor scores, which have a mean of zero and a standard deviation of one across the entire distribution of institutional investors. Listed below each factor are the means and standard deviations of the variables that comprise the factor. These variables are calculated at the end of each calendar quarter for every institution on the Spectrum database. The quarterly values are averaged over all available quarters to calculate the year-end values for each institution. These average annual values are used in the factor and cluster analyses. 
TABLE 2

Descriptive Statistics 1

Panel A. Variables used in levels analysis $(\mathrm{N}=4,314)$

\begin{tabular}{lccccc} 
& Mean & Std. Dev. & Median & Q1 & Q3 \\
\hline DISC $_{\mathrm{t}}$ & 0.5202 & 0.3113 & 0.5354 & 0.2500 & 0.8000 \\
TRA $_{\mathrm{t}}$ & 0.0963 & 0.0710 & 0.0828 & 0.0467 & 0.1283 \\
DED $_{\mathrm{t}}$ & 0.1008 & 0.0880 & 0.0790 & 0.0399 & 0.1374 \\
QIX $_{\mathrm{t}}$ & 0.2883 & 0.1239 & 0.2934 & 0.1997 & 0.3751 \\
STDRET $_{\mathrm{t}+1}$ & -4.0021 & 0.3646 & -4.0513 & -4.2405 & -3.9787 \\
MRET $_{\mathrm{t}}$ & -0.0009 & 0.2869 & -0.0233 & -0.1744 & 0.1416 \\
TVOL $_{\mathrm{t}}$ & 0.1519 & 0.1111 & 0.1236 & 0.0836 & 0.1804 \\
MV $_{\mathrm{t}}$ & 7.3575 & 1.4079 & 7.3945 & 6.4393 & 8.2961 \\
BETA $_{\mathrm{t}}$ & 0.9557 & 0.4008 & 0.9518 & 0.6846 & 1.2114 \\
IRISK $_{\mathrm{t}}$ & -4.1193 & 0.3563 & -4.1669 & -4.3583 & -3.9170 \\
LEV $_{\mathrm{t}}$ & 0.2373 & 0.1560 & 0.2253 & 0.1233 & 0.3231 \\
DP $_{\mathrm{t}}$ & 0.0287 & 0.0206 & 0.0274 & 0.0135 & 0.0407 \\
EP $_{\mathrm{t}}$ & 0.0545 & 0.0760 & 0.0643 & 0.0401 & 0.0954 \\
BP $_{\mathrm{t}}$ & 0.6385 & 0.3850 & 0.5879 & 0.3685 & 0.8426 \\
$\mathrm{SGR}_{\mathrm{t}}$ & 0.0757 & 0.1622 & 0.0655 & -0.0049 & 0.1382 \\
RATE $_{\mathrm{t}}$ & 5.6345 & 2.8704 & 6.0000 & 4.0000 & 8.0000 \\
S\&P500 $_{\mathrm{t}}$ & 0.6310 & 0.4826 & 1.0000 & 0.0000 & 1.0000 \\
\hline
\end{tabular}

where STDRET $_{t+1}=$ the log of the standard deviation of daily stock returns measured over a year's time (minimum of 125 observations)

$\mathrm{TRA}_{\mathrm{t}}, \mathrm{DED}_{\mathrm{t}}$, and $\mathrm{QIX}=$ the percentage ownership by transient, dedicated, and quasi-indexer institutions relative to total shares outstanding

$\mathrm{MRET}_{\mathrm{t}}=$ the market-adjusted buy-and-hold stock return measured over a year's time (minimum of 125 observations)

$\mathrm{TVOL}_{\mathrm{t}}=$ the average monthly trading volume relative to total share outstanding measured over a year's time $\mathrm{MV}_{\mathrm{t}}=$ the $\log$ of the market value of equity $(\mathrm{CS} \# 24 * \mathrm{CS} \# 25)$

BETA $_{t}=$ the market-model beta calculated from daily stock returns measured over a year's time (minimum of 125 observations)

$I_{R I S K}=$ the $\log$ of the standard deviation of market-model residuals calculated from daily stock returns measured over a year's time (minimum of 125 observations)

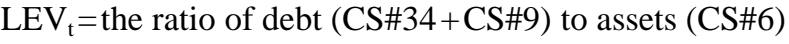

$\mathrm{DP}_{\mathrm{t}}=$ the ratio of dividends $(\mathrm{CS} \# 21)$ to market value of equity $(\mathrm{CS} \# 24 * \mathrm{CS} \# 25)$

$\mathrm{EP}_{\mathrm{t}}=$ the ratio of income before extraordinary items (CS\#18) to market value of equity (CS\#24*CS\#25)

$\mathrm{BP}_{\mathrm{t}}=$ the ratio of book value of equity (CS\#60) to market value of equity (CS\#24*CS\#25)

$\mathrm{SGR}_{\mathrm{t}}=$ the percentage change in annual sales $(\mathrm{CS} \# 12)$

RATE $_{\mathrm{t}}=$ the $\mathrm{S} \& \mathrm{P}$ stock rating $(9=\mathrm{A}+, \ldots, 1=$ not rated) (Quarterly COMPUSTAT PDA)

$\mathrm{S} \& \mathrm{P} 500_{\mathrm{t}}=$ one (zero otherwise) if the portfolio firm is in the S\&P 500 Index 
TABLE 2 (CONTINUED)

Descriptive Statistics

Panel B. Variables used in changes analysis $(\mathrm{N}=4,065)$

\begin{tabular}{lccccc} 
& Mean & Std. Dev. & Median & Q1 & Q3 \\
\hline$\Delta$ DISC $_{\mathrm{t}}$ & 0.0013 & 0.2310 & 0.0000 & -0.1111 & 0.1211 \\
$\Delta \mathrm{TRA}_{\mathrm{t}}$ & -0.0010 & 0.0616 & -0.0008 & -0.0286 & 0.0272 \\
$\Delta$ DED $_{\mathrm{t}}$ & 0.0045 & 0.0620 & 0.0015 & -0.0194 & 0.0284 \\
$\Delta \mathrm{QIX}_{\mathrm{t}}$ & 0.0036 & 0.0685 & 0.0032 & -0.0328 & 0.0402 \\
$\Delta \mathrm{STDRET}_{\mathrm{t}+1}$ & 0.0000 & 0.0290 & 0.0000 & -0.0300 & 0.0300 \\
$\Delta \mathrm{MRET}_{\mathrm{t}}$ & -0.0148 & 0.3843 & -0.0179 & -0.2472 & 0.2125 \\
$\Delta \mathrm{TVOL}_{\mathrm{t}}$ & 0.0063 & 0.0680 & 0.0031 & -0.0203 & 0.0292 \\
$\Delta \mathrm{MV}_{\mathrm{t}}$ & 0.1065 & 0.3318 & 0.0968 & -0.0823 & 0.2919 \\
$\Delta \mathrm{LEV}_{\mathrm{t}}$ & 0.0031 & 0.0714 & -0.0016 & -0.0238 & 0.0223 \\
$\Delta \mathrm{DP}_{\mathrm{t}}$ & -0.0008 & 0.0449 & 0.0000 & -0.0045 & 0.0031 \\
$\Delta \mathrm{EP}_{\mathrm{t}}$ & -0.0113 & 0.1128 & -0.0038 & -0.0283 & 0.0167 \\
$\Delta \mathrm{BP}_{\mathrm{t}}$ & -0.0197 & 0.2372 & -0.0127 & -0.1070 & 0.0733 \\
$\Delta \mathrm{SGR}_{\mathrm{t}}$ & -0.0072 & 0.2131 & -0.0050 & -0.0855 & 0.0744 \\
$\Delta \mathrm{RATE}_{\mathrm{t}}$ & 0.1749 & 1.4473 & 0.0000 & 0.0000 & 0.0000 \\
$\Delta \mathrm{SHRS}_{\mathrm{t}}$ & 0.1161 & 0.2224 & 0.0166 & 0.0038 & 0.0780 \\
\hline
\end{tabular}

where $\Delta$ STDRET $_{t+1}=$ STDRET $_{t+1}-$ STDRET $_{t}$

$$
\begin{aligned}
& \Delta \mathrm{TRA}_{\mathrm{t}}=\mathrm{TRA}_{\mathrm{t}}-\mathrm{TRA}_{\mathrm{t}-1} \\
& \Delta \mathrm{DED}_{\mathrm{t}}=\mathrm{DED}_{\mathrm{t}}-\mathrm{DED}_{\mathrm{t}-1} \\
& \Delta \mathrm{QIX}_{\mathrm{t}}=\mathrm{QIX}_{\mathrm{t}}-\mathrm{CIX}_{\mathrm{t}-1} \\
& \Delta \mathrm{MRET}_{\mathrm{t}}=\mathrm{MRET}_{\mathrm{t}}-\mathrm{MRET}_{\mathrm{t}-1} \\
& \Delta \mathrm{TVOL}_{\mathrm{t}}=\mathrm{TVOL}_{\mathrm{t}}-\mathrm{TVOL}_{\mathrm{t}-1} \\
& \Delta \mathrm{MV}_{\mathrm{t}}=\mathrm{MV}_{\mathrm{t}}-\mathrm{MV}_{\mathrm{t}-1} \\
& \Delta \mathrm{LEV}_{\mathrm{t}}=\mathrm{LEV}_{\mathrm{t}}-\mathrm{LEV}_{\mathrm{t}-1} \\
& \Delta \mathrm{DP}_{\mathrm{t}}=\mathrm{DP}_{\mathrm{t}}-\mathrm{DP}_{\mathrm{t}-1} \\
& \Delta \mathrm{EP}_{\mathrm{t}}=\mathrm{EP}_{\mathrm{t}}-\mathrm{EP}_{\mathrm{t}-1} \\
& \Delta \mathrm{BP}_{\mathrm{t}}=\mathrm{BP}_{\mathrm{t}}-\mathrm{BP}_{\mathrm{t}-1} \\
& \Delta \mathrm{SGR}_{\mathrm{t}}=\mathrm{SGR}_{\mathrm{t}}-\mathrm{SGR}_{\mathrm{t}-1} \\
& \Delta \mathrm{RATE}_{\mathrm{t}}=\mathrm{RATE}_{\mathrm{t}}-\mathrm{RATE}_{\mathrm{t}-1} \\
& \Delta \mathrm{SHRS}_{\mathrm{t}}=\mathrm{SHRS}_{\mathrm{t}}-\mathrm{SHRS}_{\mathrm{t}-1}
\end{aligned}
$$

${ }^{1}$ See figure 1 for a timeline that describes the periods over which the variables are calculated. 
TABLE 3

Regression of Institutional Ownership on Disclosure Quality ${ }^{1,2}$

\begin{tabular}{|c|c|c|c|}
\hline & $\mathrm{TRA}_{\mathrm{t}}$ & $\mathrm{DED}_{\mathrm{t}}$ & $\mathrm{QIX}_{\mathrm{t}}$ \\
\hline Intercept & $\begin{array}{r}-0.0028 \\
(0.631)\end{array}$ & $\begin{array}{r}-0.0064 \\
(0.355)\end{array}$ & $\begin{array}{r}-0.0323 \\
(0.000)\end{array}$ \\
\hline DISC $_{t}$ & $\begin{array}{l}0.0165 \\
(0.000)\end{array}$ & $\begin{array}{r}-0.0041 \\
(0.429)\end{array}$ & $\begin{array}{l}0.0274 \\
(0.000)\end{array}$ \\
\hline $\mathrm{MRET}_{\mathrm{t}}$ & $\begin{array}{l}0.0512 \\
(0.000)\end{array}$ & $\begin{array}{r}-0.0039 \\
(0.557)\end{array}$ & $\begin{array}{r}-0.0236 \\
(0.015)\end{array}$ \\
\hline $\mathrm{TVOL}_{\mathrm{t}}$ & $\begin{array}{l}0.2875 \\
(0.000)\end{array}$ & $\begin{array}{l}0.0148 \\
(0.413)\end{array}$ & $\begin{array}{l}0.1823 \\
(0.000)\end{array}$ \\
\hline $\mathrm{MV}_{\mathrm{t}}$ & $\begin{array}{l}0.0031 \\
(0.018)\end{array}$ & $\begin{array}{l}0.0015 \\
(0.628)\end{array}$ & $\begin{array}{l}0.0099 \\
(0.021)\end{array}$ \\
\hline BETA $_{t}$ & $\begin{array}{l}0.0094 \\
(0.007)\end{array}$ & $\begin{array}{r}-0.0092 \\
(0.124)\end{array}$ & $\begin{array}{l}0.0117 \\
(0.132)\end{array}$ \\
\hline IRISK $_{t}$ & $\begin{array}{r}-0.0226 \\
(0.002)\end{array}$ & $\begin{array}{c}-0.0241 \\
(0.010)\end{array}$ & $\begin{array}{r}-0.0948 \\
(0.000)\end{array}$ \\
\hline $\mathrm{LEV}_{\mathrm{t}}$ & $\begin{array}{l}0.0145 \\
(0.106)\end{array}$ & $\begin{array}{l}0.0048 \\
(0.598)\end{array}$ & $\begin{array}{l}0.0034 \\
(0.821)\end{array}$ \\
\hline $\mathrm{DP}_{\mathrm{t}}$ & $\begin{array}{r}-0.5320 \\
(0.000)\end{array}$ & $\begin{array}{r}-0.3468 \\
(0.066)\end{array}$ & $\begin{array}{r}-0.0277 \\
(0.850)\end{array}$ \\
\hline $\mathrm{EP}_{\mathrm{t}}$ & $\begin{array}{l}0.0205 \\
(0.104)\end{array}$ & $\begin{array}{r}-0.0137 \\
(0.249)\end{array}$ & $\begin{array}{l}0.0088 \\
(0.116)\end{array}$ \\
\hline $\mathrm{BP}_{\mathrm{t}}$ & $\begin{array}{l}0.0073 \\
(0.169)\end{array}$ & $\begin{array}{l}0.0116 \\
(0.038)\end{array}$ & $\begin{array}{l}0.0158 \\
(0.007)\end{array}$ \\
\hline $\mathrm{SGR}_{\mathrm{t}}$ & $\begin{array}{l}0.0386 \\
(0.000)\end{array}$ & $\begin{array}{r}-0.0147 \\
(0.212)\end{array}$ & $\begin{array}{r}-0.0041 \\
(0.621)\end{array}$ \\
\hline RATE $_{t}$ & $\begin{array}{c}-0.0002 \\
(0.769)\end{array}$ & $\begin{array}{r}-0.0028 \\
(0.000)\end{array}$ & $\begin{array}{l}0.0059 \\
(0.000)\end{array}$ \\
\hline $\mathrm{S} \& \mathrm{P} 500_{\mathrm{t}}$ & $\begin{array}{l}0.0067 \\
(0.020)\end{array}$ & $\begin{array}{l}0.0008 \\
(0.869)\end{array}$ & $\begin{array}{l}0.0427 \\
(0.000)\end{array}$ \\
\hline Average Adjusted $\mathrm{R}^{2}$ & 0.263 & 0.046 & 0.234 \\
\hline
\end{tabular}

${ }^{1}$ See table 2 for variable definitions.

${ }^{2}$ For each independent variable in these regressions, the first row is the mean coefficient from 15 yearly regressions between 1982 and 1996, and the second row is a two-sided $p$-value that tests whether this coefficient is significantly different from zero. The $p$-value uses a standard deviation calculated from the 15 yearly coefficients. The average adjusted $R^{2}$ is the average across the 15 yearly regressions. The total sample size is 4,314 while the yearly sample sizes range between 193 and 402 . 
TABLE 4

Regression of Changes in Institutional Ownership on Changes in Disclosure Quality ${ }^{1,2}$

\begin{tabular}{|c|c|c|c|}
\hline & $\Delta \mathrm{TRA}_{\mathrm{t}}$ & $\Delta \mathrm{DED}_{\mathrm{t}}$ & $\Delta \mathrm{QIX}_{\mathrm{t}}$ \\
\hline Intercept & $\begin{array}{l}0.0342 \\
(0.015)\end{array}$ & $\begin{array}{r}-0.0061 \\
(0.702)\end{array}$ & $\begin{array}{r}-0.0453 \\
(0.016)\end{array}$ \\
\hline$\Delta$ DISC $_{t}$ & $\begin{array}{l}0.0133 \\
(0.038)\end{array}$ & $\begin{array}{l}0.0084 \\
(0.433)\end{array}$ & $\begin{array}{r}-0.0103 \\
(0.232)\end{array}$ \\
\hline$\Delta$ DISC $_{t} *$ DNDISC $_{t}$ & $\begin{array}{c}-0.0062 \\
(0.607)\end{array}$ & $\begin{array}{r}-0.0112 \\
(0.435)\end{array}$ & $\begin{array}{l}0.0327 \\
(0.023)\end{array}$ \\
\hline QDISC $_{t-1}$ & $\begin{array}{l}0.0014 \\
(0.108)\end{array}$ & $\begin{array}{l}0.0000 \\
(0.992)\end{array}$ & $\begin{array}{l}0.0021 \\
(0.044)\end{array}$ \\
\hline QTRA $_{t-1}$ & $\begin{array}{r}-0.0162 \\
(0.000)\end{array}$ & & \\
\hline $\mathrm{QDED}_{\mathrm{t}-1}$ & & $\begin{array}{r}-0.0134 \\
(0.000)\end{array}$ & \\
\hline QQIX $_{t-1}$ & & & $\begin{array}{r}-0.0161 \\
(0.000)\end{array}$ \\
\hline$\Delta$ MRET $_{\mathrm{t}}$ & $\begin{array}{l}0.0155 \\
(0.019)\end{array}$ & $\begin{array}{r}-0.0034 \\
(0.367)\end{array}$ & $\begin{array}{r}-0.0239 \\
(0.001)\end{array}$ \\
\hline TVOL $_{\mathrm{t}-1}$ & $\begin{array}{l}0.0672 \\
(0.007)\end{array}$ & $\begin{array}{l}0.0581 \\
(0.002)\end{array}$ & $\begin{array}{l}0.0343 \\
(0.087)\end{array}$ \\
\hline$\Delta \mathrm{MV}_{\mathrm{t}}$ & $\begin{array}{l}0.0502 \\
(0.000)\end{array}$ & $\begin{array}{r}-0.0049 \\
(0.343)\end{array}$ & $\begin{array}{l}0.0235 \\
(0.003)\end{array}$ \\
\hline BETA $_{t-1}$ & $\begin{array}{l}0.0025 \\
(0.532)\end{array}$ & $\begin{array}{r}-0.0024 \\
(0.492)\end{array}$ & $\begin{array}{l}0.0075 \\
(0.082)\end{array}$ \\
\hline IRISK $_{t-1}$ & $\begin{array}{l}0.0019 \\
(0.537)\end{array}$ & $\begin{array}{r}-0.0085 \\
(0.055)\end{array}$ & $\begin{array}{r}-0.0162 \\
(0.001)\end{array}$ \\
\hline$\Delta \mathrm{LEV}_{\mathrm{t}}$ & $\begin{array}{r}-0.0252 \\
(0.157)\end{array}$ & $\begin{array}{l}0.0136 \\
(0.430)\end{array}$ & $\begin{array}{r}-0.0276 \\
(0.242)\end{array}$ \\
\hline$\Delta \mathrm{DP}_{\mathrm{t}}$ & $\begin{array}{r}-0.1649 \\
(0.135)\end{array}$ & $\begin{array}{l}0.2356 \\
(0.025)\end{array}$ & $\begin{array}{l}0.1647 \\
(0.369)\end{array}$ \\
\hline$\Delta \mathrm{EP}_{\mathrm{t}}$ & $\begin{array}{l}0.0160 \\
(0.061)\end{array}$ & $\begin{array}{l}0.0092 \\
(0.453)\end{array}$ & $\begin{array}{l}0.0002 \\
(0.992)\end{array}$ \\
\hline$\Delta \mathrm{BP}_{\mathrm{t}}$ & $\begin{array}{l}0.0000 \\
(0.998)\end{array}$ & $\begin{array}{r}-0.0192 \\
(0.052)\end{array}$ & $\begin{array}{l}0.0095 \\
(0.367)\end{array}$ \\
\hline$\Delta \mathrm{SGR}_{\mathrm{t}}$ & $\begin{array}{l}0.0138 \\
(0.001)\end{array}$ & $\begin{array}{r}-0.0027 \\
(0.623)\end{array}$ & $\begin{array}{r}-0.0031 \\
(0.483)\end{array}$ \\
\hline$\Delta \mathrm{RATE}_{\mathrm{t}}$ & $\begin{array}{l}0.0005 \\
(0.703)\end{array}$ & $\begin{array}{r}-0.0025 \\
(0.033)\end{array}$ & $\begin{array}{r}-0.0016 \\
(0.425)\end{array}$ \\
\hline$\Delta$ SHRS $_{\mathrm{t}}$ & $\begin{array}{c}-0.0003 \\
(0.937)\end{array}$ & $\begin{array}{r}-0.0130 \\
(0.083)\end{array}$ & $\begin{array}{r}-0.0336 \\
(0.000)\end{array}$ \\
\hline Average Adjusted $\mathrm{R}^{2}$ & 0.287 & 0.129 & 0.170 \\
\hline
\end{tabular}

${ }^{1}$ See table 2 for variable definitions.

${ }^{2}$ For each independent variable in these regressions, the first row is the mean coefficient from 14 yearly regressions between 1983 and 1996, and the second row is a two-sided $p$-value that tests whether this coefficient is significantly different from zero. The $p$-value uses a standard deviation calculated from the 14 yearly coefficients. The average adjusted $\mathrm{R}^{2}$ is the average across the 14 yearly regressions. The total sample size is 4,065 while the yearly sample sizes range between 187 and 383 . 
TABLE 5

Regression of Future Stock Return Volatility on Disclosure Quality and Institutional Ownership ${ }^{1,2}$

\begin{tabular}{|c|c|c|c|}
\hline & STDRET $_{\mathrm{t}+1}$ & STDRET $_{t+1}$ & STDRET $_{t+1}$ \\
\hline Intercept & $\begin{array}{r}-3.9479 \\
(0.000)\end{array}$ & $\begin{array}{r}-3.8993 \\
(0.000)\end{array}$ & $\begin{array}{r}-3.8926 \\
(0.000)\end{array}$ \\
\hline DISC $_{t}$ & $\begin{array}{r}-0.0215 \\
(0.062)\end{array}$ & & $\begin{array}{r}-0.0166 \\
(0.076)\end{array}$ \\
\hline $\mathrm{TRA}_{\mathrm{t}}$ & & $\begin{array}{l}0.8090 \\
(0.001)\end{array}$ & $\begin{array}{l}0.8103 \\
(0.001)\end{array}$ \\
\hline $\mathrm{DED}_{\mathrm{t}}$ & & $\begin{array}{r}-0.1971 \\
(0.003)\end{array}$ & $\begin{array}{r}-0.1976 \\
(0.003)\end{array}$ \\
\hline $\mathrm{QIX}_{\mathrm{t}}$ & & $\begin{array}{r}-0.4604 \\
(0.000)\end{array}$ & $\begin{array}{r}-0.4543 \\
(0.000)\end{array}$ \\
\hline $\mathrm{MRET}_{\mathrm{t}}$ & $\begin{array}{l}0.0510 \\
(0.303)\end{array}$ & $\begin{array}{r}-0.0116 \\
(0.804)\end{array}$ & $\begin{array}{r}-0.0109 \\
(0.817)\end{array}$ \\
\hline $\mathrm{TVOL}_{\mathrm{t}}$ & $\begin{array}{l}0.6420 \\
(0.000)\end{array}$ & $\begin{array}{l}0.5155 \\
(0.000)\end{array}$ & $\begin{array}{l}0.5148 \\
(0.000)\end{array}$ \\
\hline $\mathrm{MV}_{\mathrm{t}}$ & $\begin{array}{r}-0.0257 \\
(0.020)\end{array}$ & $\begin{array}{r}-0.0270 \\
(0.012)\end{array}$ & $\begin{array}{r}-0.0259 \\
(0.017)\end{array}$ \\
\hline $\mathrm{LEV}_{\mathrm{t}}$ & $\begin{array}{l}0.1996 \\
(0.001)\end{array}$ & $\begin{array}{l}0.1855 \\
(0.000)\end{array}$ & $\begin{array}{l}0.1872 \\
(0.000)\end{array}$ \\
\hline $\mathrm{DP}_{\mathrm{t}}$ & $\begin{array}{r}-1.9249 \\
(0.000)\end{array}$ & $\begin{array}{r}-1.4305 \\
(0.000)\end{array}$ & $\begin{array}{r}-1.4120 \\
(0.000)\end{array}$ \\
\hline $\mathrm{EP}_{\mathrm{t}}$ & $\begin{array}{r}-0.5110 \\
(0.003)\end{array}$ & $\begin{array}{r}-0.5032 \\
(0.003)\end{array}$ & $\begin{array}{r}-0.5022 \\
(0.003)\end{array}$ \\
\hline $\mathrm{BP}_{\mathrm{t}}$ & $\begin{array}{l}0.1281 \\
(0.007)\end{array}$ & $\begin{array}{l}0.1215 \\
(0.009)\end{array}$ & $\begin{array}{l}0.1215 \\
(0.008)\end{array}$ \\
\hline $\mathrm{SGR}_{\mathrm{t}}$ & $\begin{array}{r}-0.0433 \\
(0.305)\end{array}$ & $\begin{array}{r}-0.0743 \\
(0.083)\end{array}$ & $\begin{array}{r}-0.0740 \\
(0.082)\end{array}$ \\
\hline RATE $_{t}$ & $\begin{array}{r}-0.0044 \\
(0.069)\end{array}$ & $\begin{array}{r}-0.0019 \\
(0.471)\end{array}$ & $\begin{array}{r}-0.0018 \\
(0.479)\end{array}$ \\
\hline $\mathrm{S} \& \mathrm{P} 500_{\mathrm{t}}$ & $\begin{array}{r}-0.0365 \\
(0.262)\end{array}$ & $\begin{array}{r}-0.0098 \\
(0.730)\end{array}$ & $\begin{array}{c}-0.0099 \\
(0.728)\end{array}$ \\
\hline Average Adjusted $\mathrm{R}^{2}$ & 0.332 & 0.372 & 0.370 \\
\hline
\end{tabular}

${ }^{1}$ See table 2 for variable definitions.

${ }^{2}$ For each independent variable in these regressions, the first row is the mean coefficient from 15 yearly regressions between 1982 and 1996, and the second row is a two-sided $p$-value that tests whether this coefficient is significantly different from zero. The $p$-value uses a standard deviation calculated from the 15 yearly coefficients. The average adjusted $R^{2}$ is the average across the 15 yearly regressions. The total sample size is 4,314 while the yearly sample sizes range between 193 and 402 . 
TABLE 6

Regression of Future Changes in Stock Return Volatility on Changes in Disclosure Quality and Changes in Institutional Ownership ${ }^{1,2}$

\begin{tabular}{|c|c|c|c|}
\hline & $\Delta$ STDRET $_{\mathrm{t}+1}$ & $\Delta$ STDRET $_{\mathrm{t}+1}$ & $\Delta$ STDRET $_{t+1}$ \\
\hline Intercept & $\begin{array}{r}-0.0004 \\
(0.936)\end{array}$ & $\begin{array}{r}-0.0004 \\
(0.924)\end{array}$ & $\begin{array}{r}-0.0005 \\
(0.912)\end{array}$ \\
\hline$\Delta$ DISC $_{\mathrm{t}}$ & $\begin{array}{l}0.0037 \\
(0.137)\end{array}$ & & $\begin{array}{l}0.0041 \\
(0.095)\end{array}$ \\
\hline$\Delta$ DISC $_{t} *$ DNDISC $_{t}$ & $\begin{array}{r}-0.0013 \\
(0.750)\end{array}$ & & $\begin{array}{r}-0.0016 \\
(0.687)\end{array}$ \\
\hline$\Delta \mathrm{TRA}_{\mathrm{t}}$ & & $\begin{array}{l}0.0217 \\
(0.015)\end{array}$ & $\begin{array}{l}0.0210 \\
(0.020)\end{array}$ \\
\hline$\Delta \mathrm{DED}_{\mathrm{t}}$ & & $\begin{array}{r}-0.0081 \\
(0.316)\end{array}$ & $\begin{array}{r}-0.0078 \\
(0.350)\end{array}$ \\
\hline$\Delta \mathrm{QIX}_{\mathrm{t}}$ & & $\begin{array}{l}0.0056 \\
(0.400)\end{array}$ & $\begin{array}{l}0.0058 \\
(0.377)\end{array}$ \\
\hline$\Delta \mathrm{MRET}_{\mathrm{t}}$ & $\begin{array}{l}0.0064 \\
(0.001)\end{array}$ & $\begin{array}{l}0.0055 \\
(0.009)\end{array}$ & $\begin{array}{l}0.0055 \\
(0.008)\end{array}$ \\
\hline$\Delta \mathrm{TVOL}_{\mathrm{t}}$ & $\begin{array}{r}-0.0395 \\
(0.000)\end{array}$ & $\begin{array}{r}-0.0385 \\
(0.000)\end{array}$ & $\begin{array}{r}-0.0388 \\
(0.000)\end{array}$ \\
\hline$\Delta \mathrm{MV}_{\mathrm{t}}$ & $\begin{array}{r}-0.0044 \\
(0.024)\end{array}$ & $\begin{array}{r}-0.0049 \\
(0.020)\end{array}$ & $\begin{array}{r}-0.0050 \\
(0.016)\end{array}$ \\
\hline$\Delta \mathrm{LEV}_{\mathrm{t}}$ & $\begin{array}{l}0.0140 \\
(0.026)\end{array}$ & $\begin{array}{l}0.0165 \\
(0.013)\end{array}$ & $\begin{array}{l}0.0167 \\
(0.010)\end{array}$ \\
\hline$\Delta \mathrm{DP}_{\mathrm{t}}$ & $\begin{array}{r}-0.0469 \\
(0.484)\end{array}$ & $\begin{array}{r}-0.0304 \\
(0.646)\end{array}$ & $\begin{array}{r}-0.0339 \\
(0.610)\end{array}$ \\
\hline$\Delta \mathrm{EP}_{\mathrm{t}}$ & $\begin{array}{r}-0.0189 \\
(0.012)\end{array}$ & $\begin{array}{r}-0.0186 \\
(0.011)\end{array}$ & $\begin{array}{r}-0.0187 \\
(0.010)\end{array}$ \\
\hline$\Delta \mathrm{BP}_{\mathrm{t}}$ & $\begin{array}{l}0.0063 \\
(0.016)\end{array}$ & $\begin{array}{l}0.0057 \\
(0.027)\end{array}$ & $\begin{array}{l}0.0057 \\
(0.027)\end{array}$ \\
\hline$\Delta \mathrm{SGR}_{\mathrm{t}}$ & $\begin{array}{r}-0.0010 \\
(0.701)\end{array}$ & $\begin{array}{c}-0.0013 \\
(0.588)\end{array}$ & $\begin{array}{r}-0.0016 \\
(0.501)\end{array}$ \\
\hline$\Delta$ RATE $_{\mathrm{t}}$ & $\begin{array}{l}0.0000 \\
(0.916)\end{array}$ & $\begin{array}{l}0.0000 \\
(0.974)\end{array}$ & $\begin{array}{c}-0.0001 \\
(0.873)\end{array}$ \\
\hline$\Delta$ SHRS $_{\mathrm{t}}$ & $\begin{array}{l}0.0088 \\
(0.001)\end{array}$ & $\begin{array}{l}0.0083 \\
(0.001)\end{array}$ & $\begin{array}{l}0.0084 \\
(0.001)\end{array}$ \\
\hline Average Adjusted $\mathrm{R}^{2}$ & 0.051 & 0.060 & 0.058 \\
\hline
\end{tabular}

${ }^{1}$ See table 2 for variable definitions.

${ }^{2}$ For each independent variable in these regressions, the first row is the mean coefficient from 14 yearly regressions between 1983 and 1996, and the second row is a two-sided $p$-value that tests whether this coefficient is significantly different from zero. The $p$-value uses a standard deviation calculated from the 14 yearly coefficients. The average adjusted $R^{2}$ is the average across the 14 yearly regressions. The total sample size is 4,065 while the yearly sample sizes range between 187 and 383 . 